\title{
Hydrological stress as a limiting factor of the invasion of Limnoperna fortunei (Dunker, 1857) in the Upper Paraná River (Brazil)
}

\author{
Estresse hidrológico como fator limitante para a invasão de \\ Limnoperna fortunei (Dunker,1857) no Alto Rio Paraná (Brasil)
}

Mônica de Cássia Souza Campos ${ }^{1}$, Rosane Lanzer ${ }^{2}$ and Paulo de Tarso Castro ${ }^{3}$

${ }^{1}$ Fundação Centro Tecnológico de Minas Gerais - CETEC, Av. José Cândido da Silveira, 2000,

CEP 31170-000, Belo Horizonte, MG, Brazil

e-mail: monicacetec@yahoo.com.br

${ }^{2}$ Universidade de Caxias do Sul - UCS, Rua Francisco Getúlio Vargas, 1130,

CEP 95070-560, Caxias do Sul, RS, Brazil

e-mail: rlanzer@ucs.br

${ }^{3}$ Universidade Federal de Ouro Preto - UFOP, Rua Diogo de Vasconcelos, 122,

CEP 35400-000, Ouro Preto, MG, Brazil

e-mail: paulo_de_tarso@degeo.ufop.br

\begin{abstract}
Limnoperna fortunei (Dunker, 1857), is an asiatic mussel that arrived in South America in 1991. Since 2004, we have noticed that the advance of this species in the lower Paranaíba River, a tributary of the Upper Paraná River, is slow when compared to the average speed of $240 \mathrm{~km} /$ year in the Paraná River (middle and lower course). Aim: The goal of this work is to understand what factors are limiting the spread of L. fortunei in this stretch of the Paranaíba River. Methods: Its occurrence and dispersion were sampled twelve times between March 2006 and November 2007 in the Paranaíba River, including the São Simão hydroelectric reservoir. Physicochemical characteristics of the water were analysed, and a Stream Length-Gradient Index calculated for the study area. Results: Adult mussels were easily found attached to the hulls of barges that travel on this stretch of the Paraná-Tietê waterway and on vessels that were docked in the harbours of grain exporters located in São Simão (GO). However, no larvae or adults were found near the harbours or upstream from them at the São Simão hydroelectric reservoir. The $\mathrm{pH}$ and concentration of calcium and dissolved oxygen values among lotic habitats and the reservoir were similar: $\mathrm{DO}$ values were close to $7 \mathrm{mg} \cdot \mathrm{L}^{-1}$, the average $\mathrm{pH}$ was near 7 , average values of total Ca ranged between 4 and $6 \mathrm{mg} \cdot \mathrm{L}^{-1}$ and the chlorophyll- $a$ levels were not restrictive to the mussel. Conclusion: Physical and chemical water parameters show that habitats were suitable for establishment of the mussel. In addition to a low pressure of propagules, this paper proposes some hydrological variables, such as the energy of the fluvial stretches, expressed by the Stream Length-Gradient Index and changes in flow downstream of the dam as barriers to the establishment of the species, discouraging larval settlement, and decreasing survival and recruitment.
\end{abstract}

Keywords: Limnoperna fortunei, invasive species, Paraná River watershed, golden mussel.

Resumo: Limnoperna fortunei (Dunker, 1857), é um molusco asiático que chegou na América do Sul em 1991. Desde 2004 verificamos que o avanço da espécie no Baixo Rio Paranaíba, afluente do Alto Rio Paraná, é lento quando comparado com a velocidade média de $240 \mathrm{~km} /$ ano nos cursos médio e baixo do rio Paraná. Objetivo: O objetivo deste trabalho é entender quais são os fatores limitantes da dispersão de $L$. fortunei neste trecho do rio Paranaíba. Métodos: Sua ocorrência e dispersão foram amostradas doze vezes entre março de 2006 e novembro de 2007 no rio Paranaíba, incluindo o reservatório da usina hidrelétrica de São Simão. Resultados: Mexilhōes adultos foram encontrados aderidos aos cascos dos barcos que circulam neste trecho da hidrovia Paraná-Tietê e em embarcaçóes atracadas nos portos de empresas exportadoras de grãos localizadas em São Simão (GO). No entanto, larvas e adultos náo foram encontrados nas proximidades dos portos nem a montante dos mesmos, no reservatório da hidrelétrica de São Simão. O pH, a concentração de cálcio e os valores médios de oxigênio dissolvido são semelhantes entre ambientes lóticos e o reservatório: as concentrações médias de oxigênio estão próximas 
de $7 \mathrm{mg} . \mathrm{L}^{-1}$, o pH médio está em torno de 7 , os valores médios de Ca total variam entre 4 e 6 mg. $\mathrm{L}^{-1}$ e os níveis de clorofila $a$ não são restritivos para esta espécie de mexilhão. Conclusão: As variáveis físico-químicas da água indicam que os habitats são adequados para o estabelecimento da espécie. Além de uma baixa pressão de propágulos, este trabalho propóe algumas variáveis hidrológicas, tais como, a energia dos trechos fluviais e mudanças da vazáo a jusante da barragem, como barreiras para o estabelecimento da espécie, uma vez que estes aspectos podem desfavorecer a fixação e sobrevivência das larvas e diminuir o recrutamento.

Palavras-chaves: Limnoperna fortunei, espécies invasoras, Bacia do rio Paraná, mexilhão dourado.

\section{Introduction}

Limnoperna fortunei (Dunker, 1857), the golden mussel, originated in Southeast Asia and arrived in South America at the estuary of the Prata River ( $34^{\circ} 55^{\prime} \mathrm{S}$ and $57^{\circ} 49^{\prime} \mathrm{W}$ ) in 1991, likely by introduction in ballast water (Darrigran and Pastorino, 1995). This mussel has spread widely in only 10 years (Cataldo and Boltovskoy, 2000; Darrigran and Pastorino, 2003), reaching the basins of the Paraná , Paraguay, Pilcomayo and Uruguay Rivers in Argentina, Brazil, Paraguay and Uruguay (Boltovskoy and Cataldo, 1999; Mansur et al., 2004). In Brazil, the mussel's presence was first recorded in 1998 in Delta do Jacuí, Rio Grande do Sul (RS) (Mansur et al., 1999; Darrigran and Mansur, 2009). L. fortunei had an important spatial expansion from the southern part of South America to the headwaters of the Upper Paraná in Brazil from 1998-2004 (Von Rukert et al., 2004).

Previous studies have reported serious impacts of the mussel in artificial systems that require raw water (Boltovskoy and Cataldo, 1999) and natural environments (Mansur et al., 1999, 2003, 2004). Negative environmental effects are pointed, such as habitat destruction and depletion of native fauna, particularly in faunal and epibenthic organisms (Darrigran and Drago, 2000; Magara et al., 2001; Darrigran, 2002; Mansur et al., 2003; Darrigran and Damborenea, 2011).

L. fortunei possesses many of the characteristics attributed to successful invaders, that is, a short generation time, phenotypic plasticity, gregariousness, abundance in its native habitat, wide environmental tolerance and commensal association with human activity (Morton, 1973, 1982). Based on the first records of invasion by $L$. fortunei in Hong Kong, Morton $(1973,1982)$ demonstrated that this subtropical freshwater species has a broad tolerance to chemical and physical variables. In certain situations, adult mussel densities can exceed 120,000 individuals per square metre (Cataldo and Boltovskoy, 2000).
The relevance of some limnological characteristics as determinants for the occurrence of molluscs is widely debated in the literature. Calcium, total hardness, alkalinity and $\mathrm{pH}$ are identified as potentially limiting factors in the distribution of zebra mussels in North America (Hincks and Mackie, 1997). The greater sensitivity of molluscs to decreases in calcium is related to this cation's physiological role in muscle contraction, cell cohesion, nerve function and maintenance of acidbase balance (Chétail and Krampitz, 1982). The $\mathrm{pH}$ is a measure of the concentration of hydrogen ions in water, and low $\mathrm{pH}$ can prevent ion exchange. Aquatic organisms are generally adapted to the pH-neutral environments; consequently, sudden changes in $\mathrm{pH}$ can result in the disappearance of some organisms present in it. According to Claudi and Mackie (1994), $\mathrm{pH}$ and calcium are the most important variables for the growth of mollusc shells.

For adults of L. fortunei, Ricciardi (1998) cites environmental tolerance limits to $\mathrm{pH}$ greater than or equal to 6.4. According Karatayev et al. (2007), L. fortunei is tolerant of mildly acidic waters and tolerant of very low oxygen concentrations. In addition, the mussel can withstand high organic loads and industrial pollution and it can be found in high densities in waters with calcium concentrations as low as 3-4 mg. $\mathrm{L}^{-1}$. This tolerance allows the mussel to spread into a wide range of environments in the world.

Environmental characteristics of habitats have long guided the probable distribution of zebra mussels, especially in North America (Strayer, 1991). Similar environmental variables have also generated sophisticated predictive models of probable distributions (Bossenbroek et al., 2001, 2007). Although these processes have been instructive in terms of large scale distribution patterns, smaller scale phenomenon have received less attention (Kraft et al., 2002).

The goal of this work is to understand which are the factors that are limiting the spread of $L$. fortunei in this small stretch of the lower Paranaíba River and 
verify if the species could survive, in the reservoir of São Simão located immediately upstream. In addition to analysing the chemical and physical characteristics of the water, we also calculated the SL Index (Stream Length-Gradient Index) to express the hydrodynamic component of the system.

\section{Material and Methods}

\subsection{Study area}

The Paraná River is approximately $4,900 \mathrm{~km}$ in length and has a catchment area of $2,800 \mathrm{~km}^{2}$. It is the second largest river in South America, formed by the junction of the Grande and Paranaíba rivers, and it delimits the boundaries of the Brazilian states of São Paulo, Minas Gerais and Mato Grosso do Sul to approximately $20^{\circ} \mathrm{S}$ and $51^{\circ} \mathrm{W}$. Throughout its course, it also forms the boundary between Brazil and Paraguay. The Upper Paraná drains an area that is primarily a plateau, although there are several waterfalls.

The climate, according to the Köppen-Geiger classification, is tropical humid, with two welldefined seasons - a dry winter and a wet summer. The average annual rainfall is $1,200-1,800 \mathrm{~mm}$. The rainy season extends from November to March, with the wettest quarter in January, February and March; the dry season peaks in June, July and August. The months of May and September are the transitions between the dry and wet seasons, respectively. The warmer temperatures coincide with the spring-summer period in September and October, when average temperatures range from 23.7-23.9 ${ }^{\circ} \mathrm{C}$, respectively. Minimum temperatures generally occur in June and July and average $18^{\circ} \mathrm{C}$. However, the daily minimum can reach as low as $1{ }^{\circ} \mathrm{C}$ (BRASIL, 1983).

The study area was the lower Paranaíba River, a tributary of the Paraná River located between the reservoirs of the São Simão and Ilha Solteira hydropower plants (Figure 1).

\subsection{Methodology}

Monitoring was conducted from March 2006 - November 2007 and included 12 collection periods. The sampling stations were distributed upstream and downstream of the reservoir of São Simão formed by the Paranaíba River which is part of the Paraná River Basin.
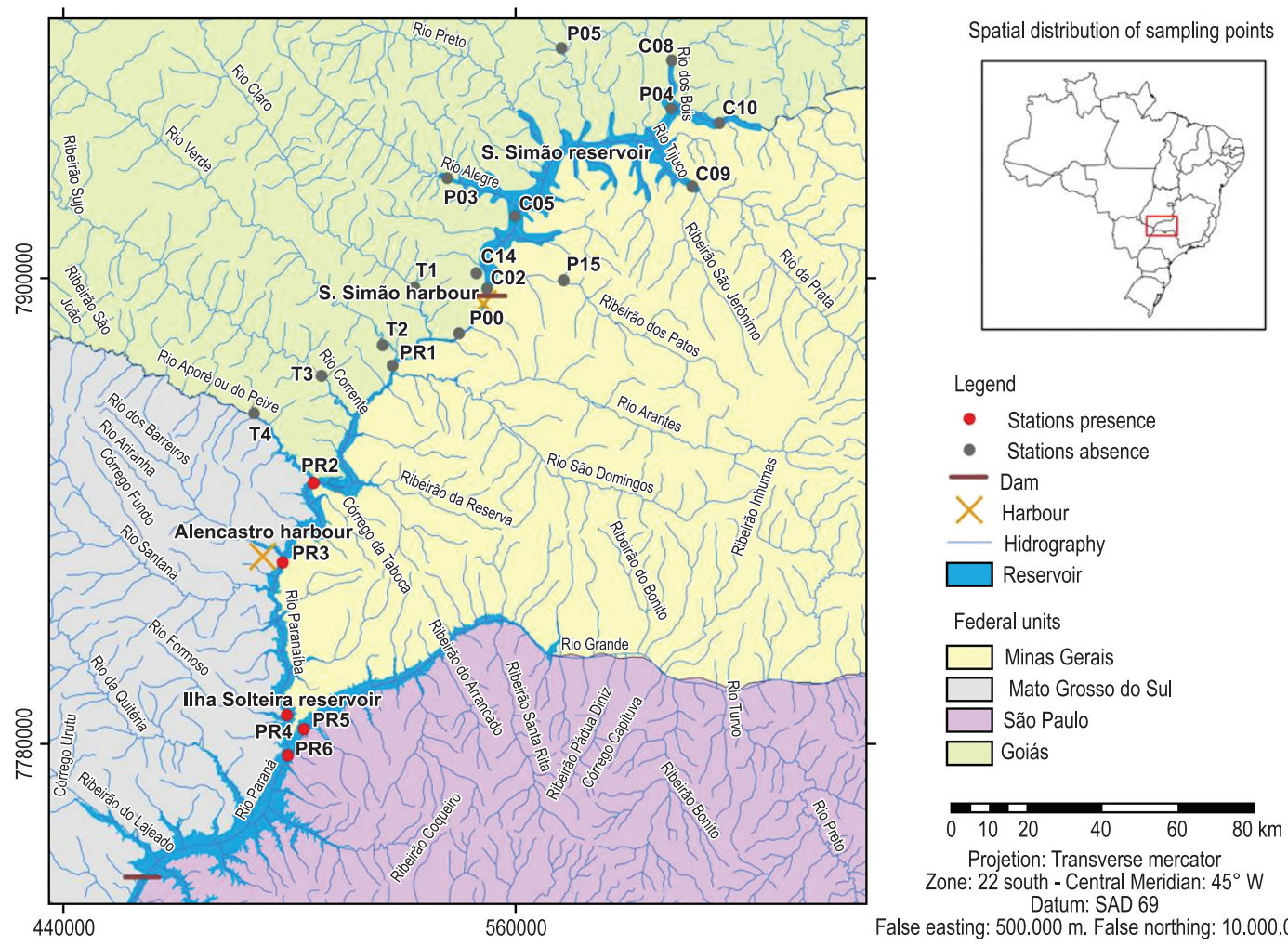

Projetion: Transverse mercator

Zone: 22 south - Central Meridian: $45^{\circ} \mathrm{W}$ Datum: SAD 69 False easting: $500.000 \mathrm{~m}$. False northing: 10.000 .000

Figure 1. Sampling stations upstream and downstream from São Simão HPP, the watershed of the Upper Paraná River, Brazil. 
Samples were collected in the main channel and along the banks of the large Paraná, Grande and Paranaíba rivers, within the reservoir of São Simão and its tributaries, and within the tributaries of the right bank of the Paranaíba River downstream from the dam (Figure 1). The data obtained in the margins and centre of the channel are expressed as averages for each sampling station. The total distance between the sampling sites along the Paranaíba River downstream of the dam was approximately $120 \mathrm{~km}$ and the total area of the reservoir is about $774 \mathrm{~km}^{2}$.

To characterise the water quality associated with the presence or potential risk of invasion by the mussel, we collected physical and chemical data on the subsurface. The measurements of water temperature $\left({ }^{\circ} \mathrm{C}\right)$, conductivity $\left(\mu \mathrm{S} . \mathrm{cm}^{-1}\right)$, $\mathrm{pH}$, dissolved oxygen (DO, mg. $\left.\mathrm{L}^{-1}\right)$, and turbidity (NTUs) were taken in situ using an automatic HORIBA model U10 meter. Samples of calcium (mg. $\left.\mathrm{L}^{-1}\right)$, alkalinity $\left(\mathrm{mg} \mathrm{CaCO} . \mathrm{L}^{-1}\right)$ nitrogen nitrate (mg. $\mathrm{L}^{-1}$ ) and total phosphorus (mg. $\mathrm{L}^{-1}$ ) were taken and analysed according to the methods of the APHA (2005). The chlorophyll-a level was determined in triplicate according to methods SM - 1002G and IBP No 12 (Vollenweider et al., 1974). Total hardness $\left(\mathrm{mg} \mathrm{CaCO} . \mathrm{L}^{-1}\right)$ was measured using the titrimetric method according to ABNT (1995). The water transparency was measured in lentic environments using a Secchi disk.

Limnoperna fortunei densities were monitored in all collections by sampling the planktonic larval stages, post larvae and adults. Larval samples were collected in triplicate approximately $20 \mathrm{~cm}$ from the surface using horizontal tows with a $35 \mu \mathrm{m}$ mesh plankton net along the limnetic zone or near the banks. The volume filtered at each tow was estimated by a flowmeter (Kahlsico Model 92022, USA). Once collected, the samples were placed in $250 \mathrm{~mL}$ bottles, fixed in $4 \%$ neutralised formalin and transported to the laboratory for analysis. The mussels were identified and divided into larval, post larvae, or adult stages following the classification of Choi and Shin (1985), Cataldo and Boltovskoy (2000) and Santos et al. (2005). Larvae $(<0.250 \mu \mathrm{m})$ were counted under an inverted microscope at $10 \times$ magnification. The samples were concentrated to $80 \mathrm{~mL}$ and counted in their entirety or in five $10 \mathrm{~mL}$ aliquots after being transferred via a Hensel-Stempel pipette to a $10 \mathrm{~mL}$ reticulated rectangular chamber made of plexiglass.

Although L. fortunei produces byssus and preferentially inhabits hard substrates, we commonly observed adults living on gravel and stone bottoms along the margins and even on individuals of the genus Corbicula (Muller, 1774). Therefore, to evaluate the presence and quantity of post larvae and adults ( $>250 \mu \mathrm{m}$ shell length), we sampled in the gravelly and sandy sediments of the littoral region. We obtained five sediment samples distributed approximately every $10 \mathrm{~m}$ along the sampling station. The collection of adults was made using a "saucepan" (Malek, 1968) $15 \mathrm{~cm}$ in diameter and made of $0.25 \mathrm{~mm}$ screen mesh. After collection, each sample was placed in a separate plastic bag and preserved with $10 \%$ formalin.

We also used artificial substrata to assess the settlement of pediveligers. We installed bricks $(20 \mathrm{~cm} \times 30 \mathrm{~cm})$ in triplicate, which, after an initial exposure of 30 days, underwent mechanical removal of any material that had adhered to it. In addition to the bricks, we used artificial substrata made of wood in the form of a cross (Matsui et al., 2001). Densities of mussels on these wood substrates were monitored by removing all material in a $15 \times 15 \mathrm{~cm}$ area over each group of three crosses every three months. The crosses were installed along a vertical axis at $0.5 \mathrm{~m}$ intervals and used the bricks as weights. The monitoring of mussel settlement on the crosses suffered discontinuities because of vandalism and from high water levels that prevented the removal of crosses. Therefore, we had three relatively continuous periods of monitoring the wood substrates: (1) March 2006 - January 2007, (2) November 2006 - May 2007 and (3) May 2007 - November 2007.

In the laboratory, the samples were sorted by sieves with $0.25-2.0 \mathrm{~mm}$ mesh sizes. We separated specimens under a stereomicroscope at $40 \times$ and $10 \times$ magnifications. The bodies were preserved in $70 \%$ alcohol. The methods outlined for sampling of larvae, pediveligers and adults followed procedures described by APHA (2005) and Downing and Rigler (1984), with adjustments according to Campos (2003).

Finally, we used the SL Index to represent the energy of the fluvial regions across the study area and linked it to the spatial distribution of the mussel. We used the SL Index to infer the energetic force of the fluvial courses and, hence, their shear stress (Hack, 1973; Etchebehere et al., 2006). This index was used to indirectly represent the hydraulic component in the system studied because we could not directly measure the flow at the time of collection and due to lack of fluviometric monitoring stations in this river stretch. 
The use of the SL Index is applicable because the speed of the current may be a factor in the dispersion pattern of the planktonic larval stage of the mussels. Because Limnoperna free-living larvae take 10-20 days to reach the settling stage depending on current speed, they can be recorded hundreds and even thousands of kilometres downstream from their parent population (Cataldo et al., 2005).

The equation representing the straight longitudinal profile on a semi-logarithmic scale is (Equation 1):

$$
\mathrm{H}=\mathrm{C}-\mathrm{k} \log _{6} \mathrm{~L}
$$

where $\mathrm{H}$ is the altitude at a point in the profile, $\mathrm{L}$ is the horizontal distance from the river in question, and $\mathrm{C}$ and $\mathrm{k}$ are constants. The tangent of the profile (slope) is derived from the previous Equation 2:

$\frac{\mathrm{dH}}{\mathrm{dL}}=\mathrm{kL}^{-1}$ or $\mathrm{S}=\frac{\mathrm{k}}{\mathrm{L}}$

and can also be presented in the form $\mathrm{SL}=\mathrm{k}$. Its value (the slope of the semi-logarithmic profile) can vary within a river as a whole but is constant for each line segment within a longitudinal profile.

From empirical evidence Hack noted (Hack and Young, 1959), that the value of the SL product is directly related to the competence of a river (the competence of a river is the maximum particle size that it is able to transport, as the velocity of the river increases it is able to transport larger particles and so its competence increases). Rivers typically have the following relationship between the channel slope (S), the length (L) and average size of particles forming the bed load (M) (Equation 3):

$$
S=25 \frac{M^{0,6}}{L}
$$

The variables needed to calculate the SL Index (altimetric difference, or amplitude of the topographic drainage channel and its length) were taken from a Digital Terrain Model done on the contour shapefile format using the ArcGIS 3D Analyst 9.3 tool. These parameters were tabulated and associated to each vector that represents each river of the basin analyzed. The calculated values of SL Index were then plotted for spatial interpolation according Etchebehere et al. (2004) using the ArcGIS Spatial Analyst and Geostatistical Analyst extensions and the Inverse Distance Weighting (IDW) interpolator. This interpolator was used to generate a continuous surface with the SL Index informations represented in a map.

\subsection{Statistical analysis}

We performed a cluster analysis using the UPGMA method with Euclidean distances to define the groups in terms of their physical-chemical conditions, using the data collected on water temperature, conductivity, $\mathrm{pH}$, dissolved oxygen, turbidity, alkalinity, calcium, hardness, phosphorus, nitrate and chlorophyll on the set of stations located on the Paranaíba River, downstream of the dam of São Simão, its right bank tributaries and stations located on the Grande and Paraná Rivers.

The spatial variation of the physical-chemical properties of water, chlorophyll- $a$ and L. fortunei density was assessed by applying a one-way ANOVA or a Kruskal-Wallis test: for non-normal distribution cases. A two-factor ANOVA (stations and year) was used to compare the chemical and physical characteristics of the Paranaíba, Grande and Paraná Rivers at all the sampling stations.

A Student's t-test was used to compare variations in physical-chemical characteristics of the water due to the rainy season and drought.

Analyses were performed and graphed using STATISTIC 7 software (StatSoft South America, São Caetano do Sul - SP, Brazil).

\section{Results}

\subsection{Spatial distribution of L. fortunei}

In this study, we did not find L. fortunei established within the reservoir of São Simão (stations C02, C14, C05, C08, C09 and C10 in Figure 1) or in the tributaries of the reservoir ( $\mathrm{P} 03$, P04, P05, P15). Among the tributaries of the right bank of the Paranaíba River, including the Claro (T1), Verde (T2), Corrente (T3) and Aporé (T4) Rivers, the mussel was only found in the Aporé River at its confluence with the waters of Paranaíba (PR2).

Larvae and adults were found at stations PR2, PR3 and PR4 in the Paranaíba River and at stations PR6 on the Paraná River and PR5 in Grande River, which indicates the establishment of the mussels just at the level of the confluence of the main river with its tributary, the Aporé River.

The average larval densities were low in the Paranaíba (that includes stations P00-PR4), Grande (PR5) and Paraná (PR6) Rivers, never exceeding 300 ind. $\mathrm{m}^{-3}$, as shown in Figure 2a. We noted a gradient of longitudinal distribution, which increased significantly from upstream to downstream along the river. Mussel larvae were found in greater density at station PR3 of the 
Paranaíba River (Kruskal-Wallis test: $\mathrm{H}=58.69$ $\mathrm{p}=0.0001)$ and downstream.

Adults were found in sediments (Figure 2b) presenting significantly different densities between the stations (Kruskal-Wallis test: $\mathrm{H}=29.09$ $\mathrm{p}=0.0064)$. The average densities of mussels in sandy and gravelly sediments were also low and did not exceed an average of 300 ind. $\mathrm{m}^{-2}$. The maximum densities of adults were 1079 ind. $\mathrm{m}^{-2}$ at the PR4 station in 2006 and 2106 ind. $\mathrm{m}^{-2}$ at the PR5 station (Grande River) in 2007. In the Paranaíba River (station PR3) in 2006, a maximum of 847 ind. $\mathrm{m}^{-2}$ were found.

The colonisation on artificial ceramic bricks and wood substrates, was higher in PR3 and PR4 stations than the others (Figure 3), being spatially differentiated (Kruskal-Wallis test: $\mathrm{H}=48.55$ $\mathrm{p}=0.0000)$. On the wood substrates we observed the highest recruitment at the PR3 station $(\mathrm{H}=15.85 \mathrm{p}=0.0032)$.
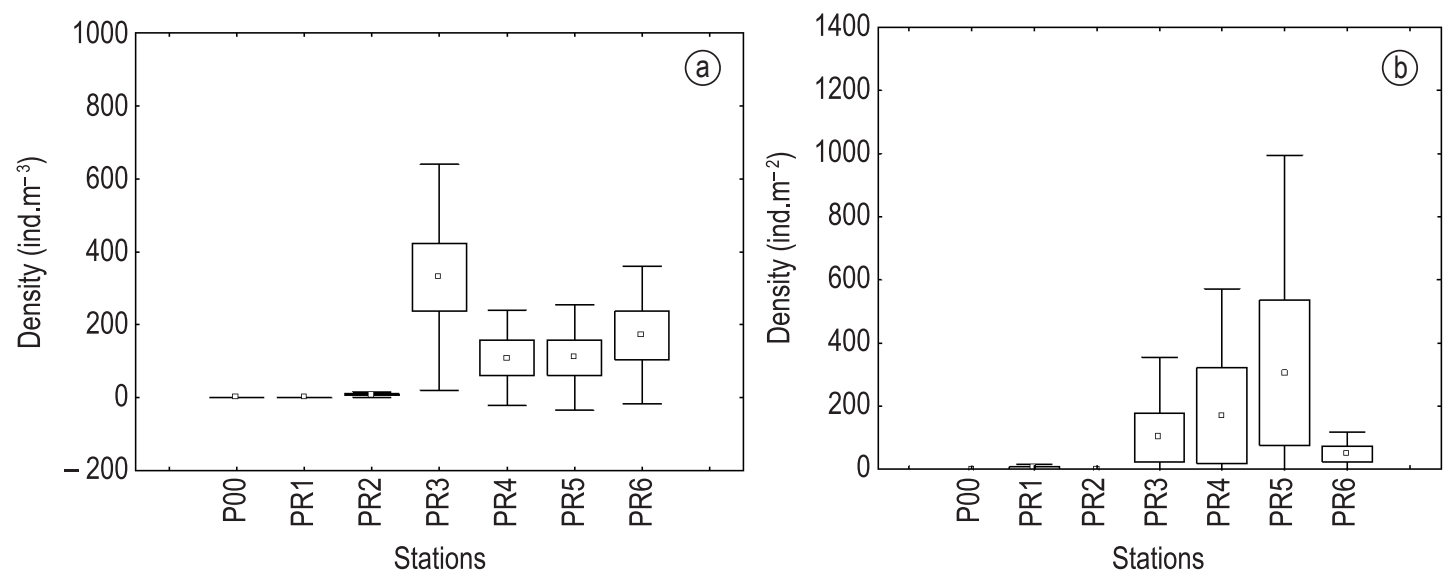

Figure 2. a) Density of larvae (ind. $\mathrm{m}^{-3}$ ) and b) density of adults (ind. $\mathrm{m}^{-2}$ ) in Paranaíba River (P00 to PR4), Grande River (PR5) and Paraná River (PR6), for the period 2006 - 2007.
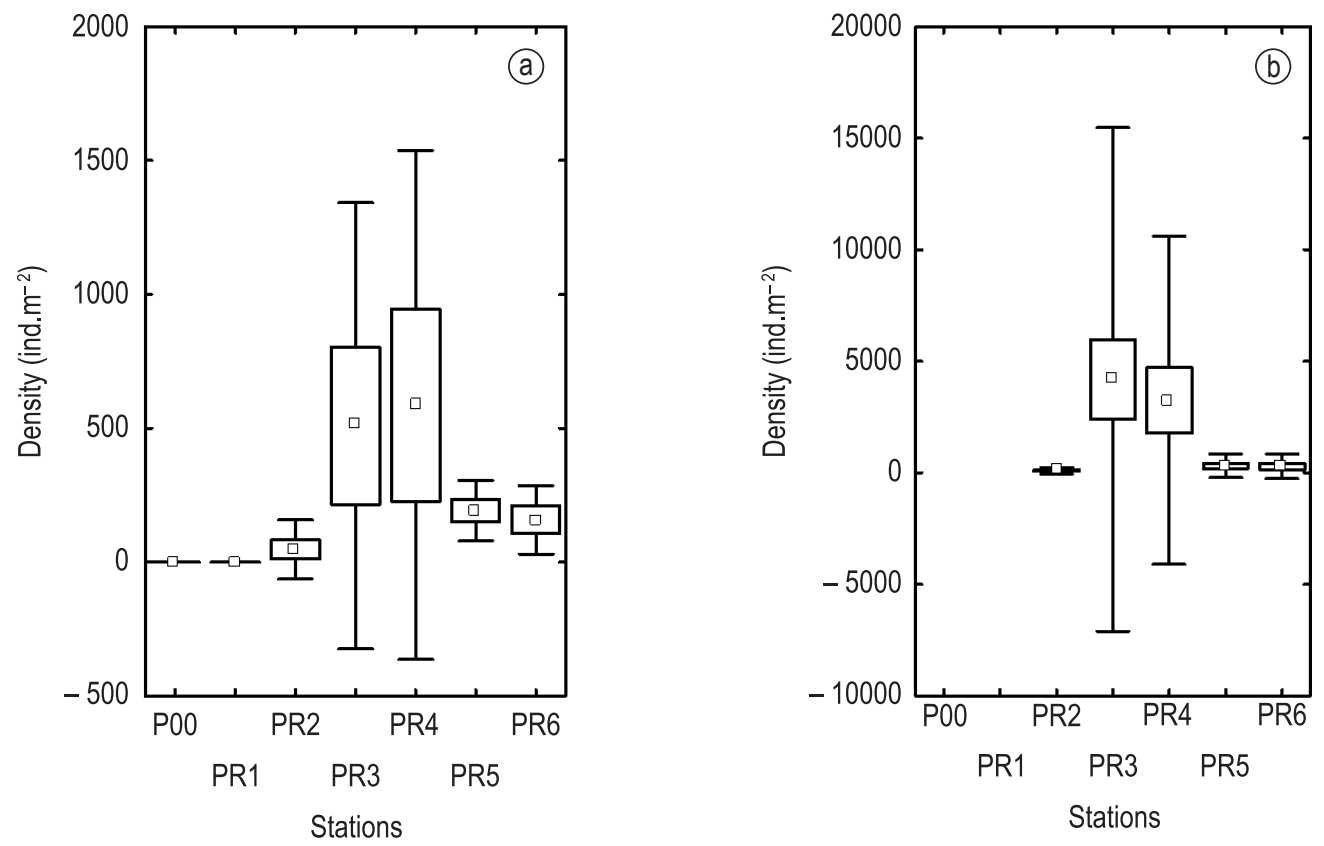

Figure 3. a) Settlement on ceramic and b) settlement on wood in the Paranaíba River (P00 - PR4), Grande River (PR5) and Paraná River (PR6), in 2006 and 2007. 
Larvae

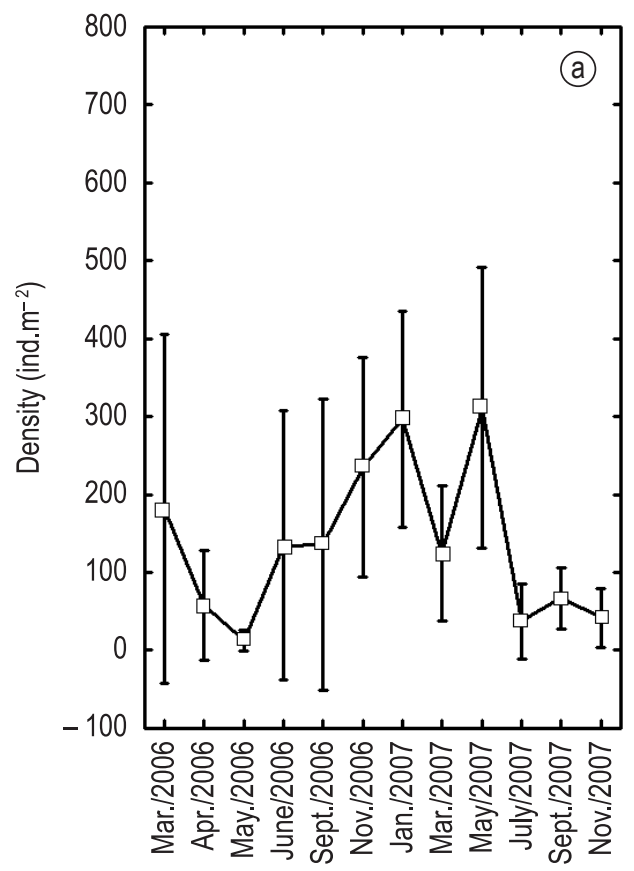

Post larvae and adults

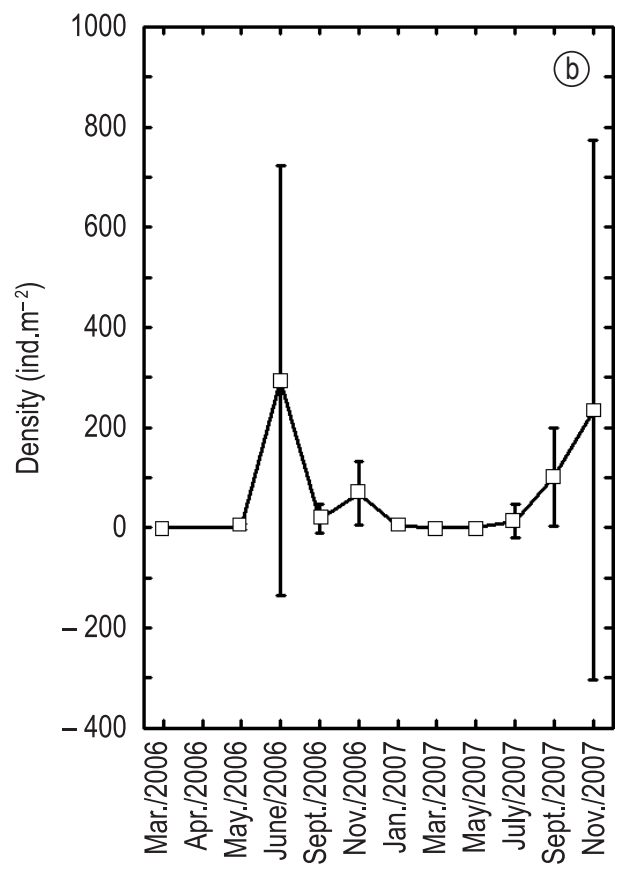

Figure 4. Density variation over time of a) planktonic larvae (ind. $\mathrm{m}^{-3}$ ), b) post larvae and adults on sediments (ind. $\mathrm{m}^{-2}$ ) during 2006 and 2007.

\subsection{Temporal variations in L. fortunei density}

The average density of larvae and adults in sediments of the sampled population did not show an increase over time (Figure 4). The high standard deviation is related to the spatial variability of the Limnoperna distribution among the sampling stations.

In general, there was not a trend of increasing settlement over time when we analyzed the cumulative density of colonisation on the wooden crosses exposed during different periods of monitoring and the colonisation of bricks which were regularly scraped clean (Figure 5).

However, there was a clear seasonal fluctuation in the settlement and colonisation on the artificial substrates (Figure 6). The settlement on ceramic substrates (Figure 6a) was greater in warmer months and during higher rainfall. During the two years monitored, there was a rise in the rates of recruitment from September-January. Colonisation on bricks reached a maximum in January 2007, with an average density of 700 ind. $\mathrm{m}^{-2}$.

The settlement on both the wood and ceramic substrates was greater in the rainy season and in hot months versus the colder months $(F=9.83$ $\mathrm{p}=0.000$ ). This difference was especially significant for wooden crosses installed from May - November
2007, which had greater colonisation in November than in the other months (Kruskal-Wallis test: $\mathrm{H}=10.40 \mathrm{p}=0.0055$ ).

The mensal fluctuation in larval density at PR3 station is shown in the Figure 7. There were peaks in larval planktonic density in October and December 2006 and October 2007, when the maximum larval densities reached 1000-1500 ind. $\mathrm{m}^{-3}$. Minimum densities of veligers were recorded during July and August in 2006 and 2007 (Kruskal-Wallis test: $\mathrm{H}=17.48340 \mathrm{p}=0.0145)$.

These results show that although seasonal fluctuations occur, an overall trend of increasing population density does not exist.

\subsection{Physical and chemical characteristics of the water downstream of the São Simão hydroelectric power plant, the Paranaiba River and tributaries}

\subsubsection{Physical and chemical spatial characterisation}

Table 1 shows the mean, minimum and maximum values of chemical and physical variables of water from rivers in the Upper Paraná watershed.

- Paranaíba River, Grande River and Paraná River

The surface waters of the Paranaíba River showed average temperatures of $25-26^{\circ} \mathrm{C}$ between 

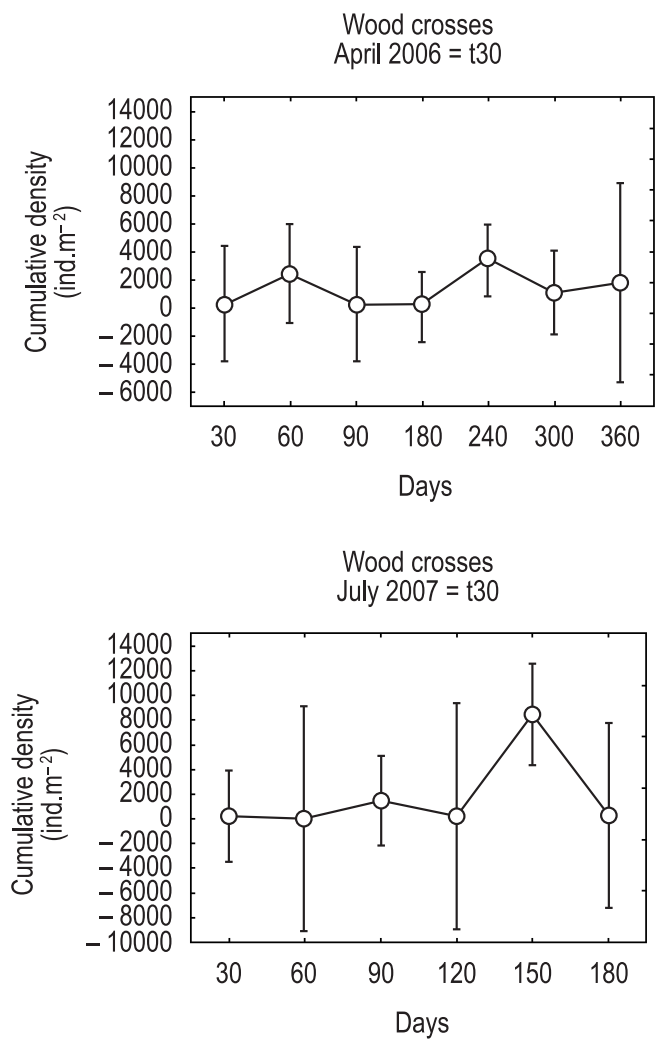

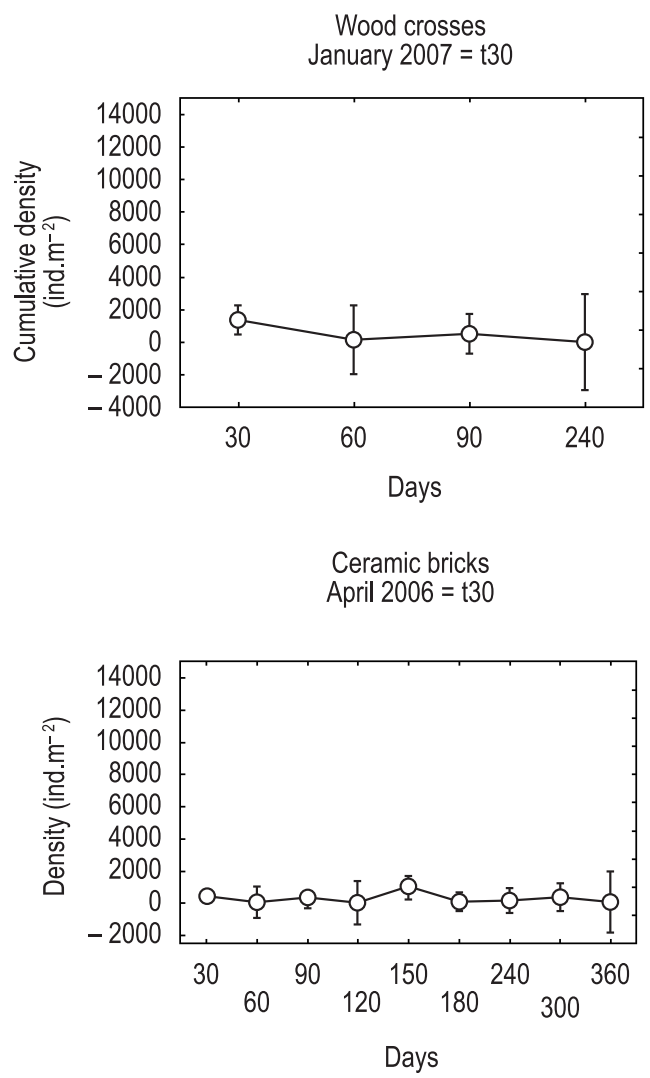

Figure 5. Temporal variation in mussel settlement (ind. $\mathrm{m}^{-2}$ ) on artificial wood substrates exposed, and ceramic substrates (ind. $\mathrm{m}^{-2}$ ) for different intervals during 2006 - 2007.
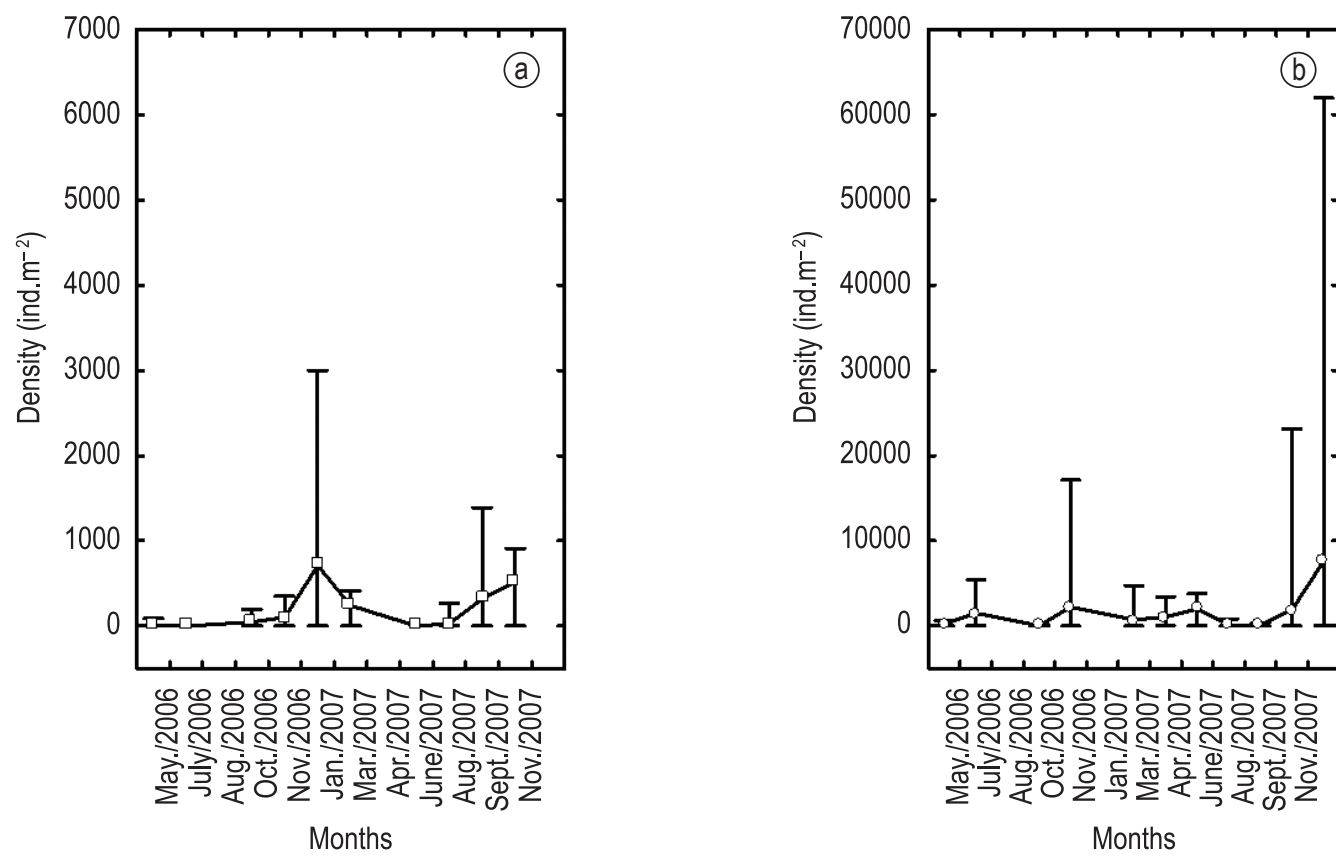

Figure 6. Temporal variation in the settlement on a) ceramic and b) wood substrates exposed on the Paranaíba, Grande and Paraná Rivers. 
Table 1. Mean, minimum and maximum values of chemical and physical variables of water from rivers on the Upper Paraná watershed downstream of the São Simão dam.

\begin{tabular}{|c|c|c|c|c|c|c|c|c|}
\hline $\begin{array}{c}\text { Rivers } \\
\text { Stations } \\
\text { UPGMA group }\end{array}$ & & $\begin{array}{c}\text { Paranaíba } \\
\text { P00 - PR4 } \\
1\end{array}$ & $\begin{array}{c}\text { Paraná } \\
\text { PR6 } \\
1\end{array}$ & $\begin{array}{c}\text { Grande } \\
\text { PR5 } \\
2\end{array}$ & $\begin{array}{l}\text { Aporé } \\
\text { T4 } \\
3\end{array}$ & $\begin{array}{c}\text { Claro } \\
\text { T1 } \\
3\end{array}$ & $\begin{array}{c}\text { Corrente } \\
\text { T3 } \\
3\end{array}$ & $\begin{array}{c}\text { Verde } \\
\text { T2 } \\
3\end{array}$ \\
\hline \multirow[t]{3}{*}{ Water temperature $\left({ }^{\circ} \mathrm{C}\right)$} & Mean & 25.92 & 26.16 & 26.19 & 23.91 & 24.06 & 24.05 & 23.89 \\
\hline & Min. & 18.00 & 23.63 & 22.97 & 19.30 & 20.30 & 20.30 & 19.90 \\
\hline & Max. & 30.40 & 29.70 & 29.63 & 28.10 & 28.80 & 28.90 & 27.90 \\
\hline \multirow[t]{3}{*}{ Secchi disc (m) } & Mean & 2.08 & 3.33 & 4.33 & & & & \\
\hline & Min. & 0.30 & 1.27 & 1.70 & & & & \\
\hline & Max. & 5.35 & 4.73 & 7.00 & & & & \\
\hline \multirow[t]{3}{*}{ Conductivity $\left(\mu \mathrm{S} . \mathrm{cm}^{-1}\right)$} & Mean & 37.22 & 41.39 & 47.29 & 32.12 & 21.53 & 19.46 & 19.23 \\
\hline & Min. & 23.70 & 36.33 & 44.33 & 23.50 & 17.90 & 14.00 & 14.90 \\
\hline & Max. & 58.00 & 53.47 & 55.00 & 43.70 & 26.00 & 33.00 & 25.00 \\
\hline \multirow[t]{3}{*}{$\mathrm{pH}$} & Mean & 6.82 & 6.83 & 6.81 & 6.54 & 6.91 & 6.47 & 6.75 \\
\hline & Min. & 5.83 & 6.27 & 6.04 & 5.46 & 6.00 & 5.64 & 6.22 \\
\hline & Max. & 7.89 & 7.70 & 7.87 & 7.22 & 7.70 & 7.50 & 7.55 \\
\hline \multirow[t]{3}{*}{ Dissolved oxygen $\left(\mathrm{mg} \cdot \mathrm{L}^{-1}\right)$} & Mean & 7.75 & 7.48 & 7.53 & 7.48 & 7.83 & 7.55 & 8.76 \\
\hline & Min. & 5.10 & 6.60 & 5.70 & 5.50 & 6.80 & 6.80 & 7.50 \\
\hline & Max. & 9.60 & 8.00 & 8.70 & 9.00 & 9.00 & 8.30 & 10.40 \\
\hline \multirow[t]{3}{*}{ Turbidity (NTU) } & Mean & 6.23 & 4.75 & 2.71 & 17.68 & 33.87 & 12.43 & 49.48 \\
\hline & Min. & 0.08 & 0.63 & 0.19 & 2.00 & 2.68 & 2.00 & 2.88 \\
\hline & Max. & 44.00 & 21.33 & 11.67 & 48.00 & 97.00 & 28.00 & 133.00 \\
\hline \multirow[t]{3}{*}{ Alkalinity (mg. $\mathrm{L}^{-1} \mathrm{CaCO}_{3}$ ) } & Mean & 13.68 & 12.05 & 13.14 & 9.76 & 6.47 & 7.51 & 5.83 \\
\hline & Min. & 2.00 & 2.30 & 2.40 & 2.50 & 1.80 & 1.70 & 1.70 \\
\hline & Max. & 55.40 & 19.55 & 33.30 & 15.50 & 9.50 & 16.70 & 8.40 \\
\hline \multirow[t]{3}{*}{ Total calcium (mg. $\left.\mathrm{L}^{-1}\right)$} & Mean & 4.16 & 4.15 & 3.95 & 3.43 & 2.54 & 2.49 & 2.14 \\
\hline & Min. & 1.87 & 2.74 & 2.87 & 2.58 & 1.73 & 1.65 & 1.36 \\
\hline & Max. & 23.50 & 6.40 & 6.80 & 3.93 & 3.88 & 3.54 & 3.46 \\
\hline \multirow[t]{3}{*}{ Hardness $\left(\mathrm{mg} \cdot \mathrm{L}^{-1} \mathrm{CaCO}_{3}\right)$} & Mean & 16.71 & 15.81 & 16.36 & 17.07 & 11.93 & 12.17 & 10.33 \\
\hline & Min. & 5.70 & 10.05 & 9.80 & 9.70 & 7.90 & 8.00 & 6.40 \\
\hline & Max. & 24.80 & 18.80 & 20.00 & 21.80 & 13.40 & 14.90 & 12.20 \\
\hline \multirow[t]{3}{*}{ Total phosphate $\left(\mathrm{mg} \cdot \mathrm{L}^{-1}\right)$} & Mean & 0.02 & 0.02 & 0.03 & 0.02 & 0.03 & 0.03 & 0.03 \\
\hline & Min. & 0.01 & 0.01 & 0.01 & 0.01 & 0.01 & 0.01 & 0.01 \\
\hline & Max. & 0.06 & 0.08 & 0.10 & 0.05 & 0.08 & 0.13 & 0.07 \\
\hline \multirow[t]{3}{*}{ Nitrate $\left(\mathrm{mg} \cdot \mathrm{L}^{-1}\right)$} & Mean & 0.07 & 0.07 & 0.07 & 0.02 & 0.02 & 0.02 & 0.05 \\
\hline & Min. & 0.01 & 0.02 & 0.01 & 0.01 & 0.01 & 0.01 & 0.01 \\
\hline & Max. & 0.14 & 0.15 & 0.18 & 0.03 & 0.04 & 0.03 & 0.18 \\
\hline \multirow[t]{3}{*}{ Chlorophyll-a $\left(\mu \mathrm{g} \cdot \mathrm{L}^{-1}\right)$} & Mean & 12.16 & 4.74 & 6.31 & 1.77 & 9.11 & 3.39 & 6.13 \\
\hline & Min. & 0.00 & 1.60 & 1.25 & 0.00 & 0.00 & 1.42 & 0.07 \\
\hline & Max. & 242.22 & 11.48 & 17.00 & 4.85 & 58.50 & 6.41 & 21.63 \\
\hline
\end{tabular}

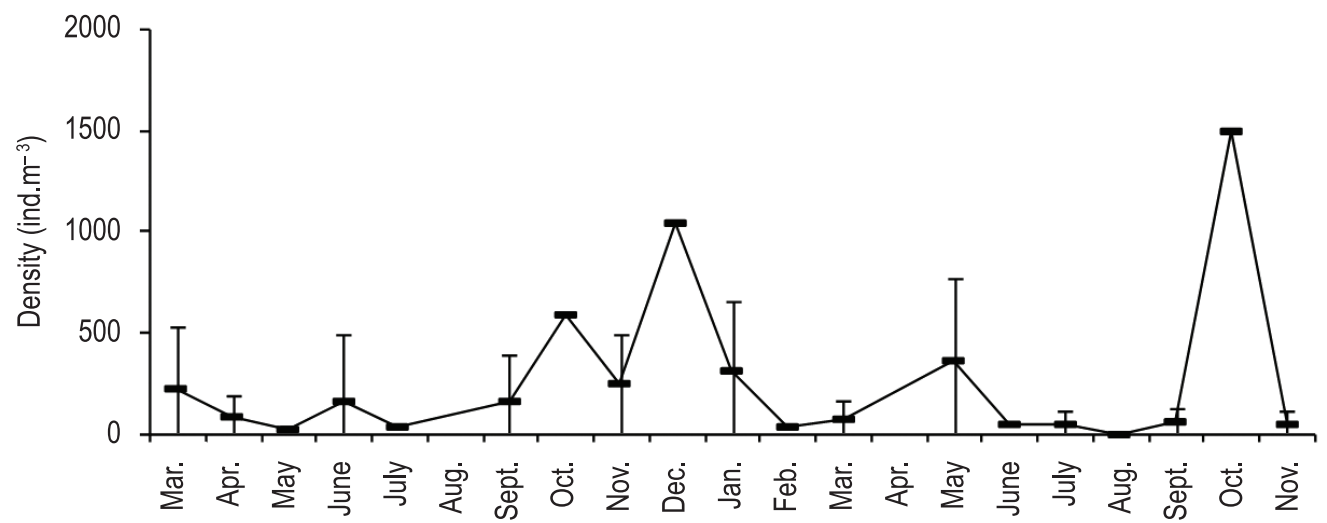

Figure 7. Mensal fluctuation of larval average density. 
March 2006 and November 2007, with a range of $18.0-30.4^{\circ} \mathrm{C}$ (Table 1 ). The conductivity of the water was low, remaining near $36 \mu S . \mathrm{cm}^{-1}$. The water of the Paranaíba River could be considered soft in the region assessed; its mean calcium concentration was approximately $4.1 \mathrm{mg} . \mathrm{L}^{-1}$, with a range of $1.8-23 \mathrm{mg} \cdot \mathrm{L}^{-1}$. The average $\mathrm{pH}$ was always above 6.8 . The nitrate level was generally higher $\left(0.07 \mathrm{mg} . \mathrm{L}^{-1}\right)$ than the reference range of 0.05 to $0.2 \mathrm{mg} . \mathrm{L}^{-1}$ for unpolluted rivers. The total phosphate level $\left(\mathrm{P}-\mathrm{PO}_{4}\right)$ was higher at stations upstream of the Paranaíba river and was highest at the PR1 station (Kruskal-Wallis test: $\mathrm{H}=24.60$ $\mathrm{p}=0.0001$; multiple comparison test: $\mathrm{p}<0.05$ ), which coincided with the peak of chlorophyll-a content at the same station. The phosphorus was not high (average $=0.02 \mathrm{mg} \cdot \mathrm{L}^{-1}$ ) compared to reference values of phosphorus in unpolluted lotic waters, which are around $0.025 \mathrm{mg} . \mathrm{L}^{-1}$. The minimum dissolved oxygen in the surface layers of the Paranaíba River was $5.1 \mathrm{mg} . \mathrm{L}^{-1}$; therefore, the average concentration was not a limiting factor to the aquatic life. The turbidity was low (6.2 NTUs), but the transparency measured by the Secchi disk was different between the stations $(F=5.6$ $\mathrm{p}=0.000)$. The transparency in the Paranaíba River at station PR4 immediately upstream of the confluence with the Paraná River was significantly higher than in other stations (P00, PR1, PR2, and PR3). This increased transparency takes place mainly along the portion of the Paranaíba River that is influenced by the backwater reservoir of Ilha Solteira, the first Paraná River dam. In this region where the water speed is reduced and there is a greater deposition of suspended solids, there is an increase in transparency and reduction in turbidity $\left(R^{2}=0.47\right.$ between the logarithm of turbidity and Secchi).

Comparing the limnological characteristics of the surface water at the Paranaíba River stations with those placed in the Grande and Paraná Rivers, we found some similarity in their waters and stability during the two years of observation (Figure 8). Except for $\mathrm{pH}$ and transparency, there were no significant differences in the two-way ANOVA for the water surface temperature, conductivity, alkalinity, calcium and hardness, total phosphate, nitrate, turbidity or chlorophyll when considering the year and where the samples were collected. The average transparency of the waters of the Grande River $(4.3 \mathrm{~m})$ was greater than in the Paranaíba or Paraná Rivers $(\mathrm{F}=5.41 \mathrm{p}=0.0002)$.

The water $\mathrm{pH}$ showed no significant variation spatially. The average $\mathrm{pH}$ of the water was 6.8 , with a range of 5.8-7.9. In 2006, the $\mathrm{pH}$ of the water was close to neutral (average $=6.99$ ) while in 2007, it averaged 6.68 .

The values of chlorophyll-a, less than $12.2 \mathrm{mg} . \mathrm{L}^{-1}$, were similar between the Paranaíba, Grande and Paraná Rivers.

- Right bank tributaries (Claro, Verde, Corrente and Aporé Rivers)

In short, from the standpoint of the physiochemistry of the water, the tributaries along the right bank of the Paranaíba River differ from the highest-ranking rivers - the Paranaíba, Paraná and

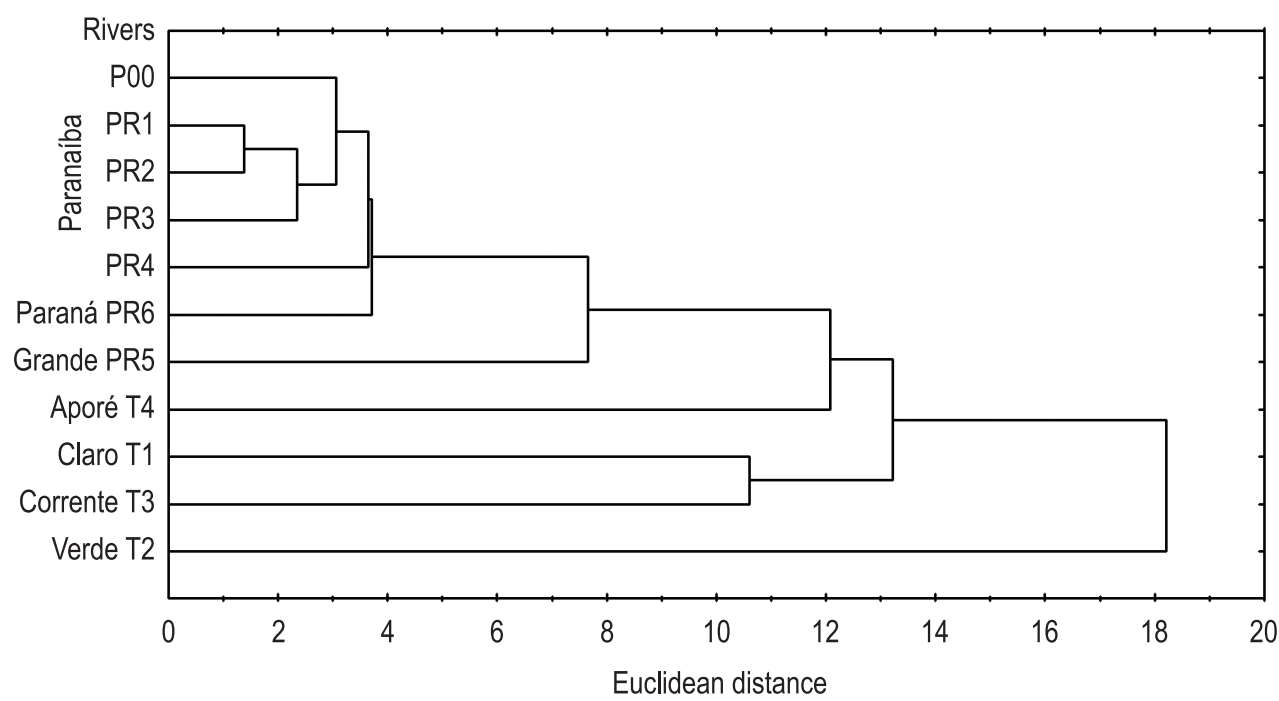

Figure 8. Grouping of sampling stations according to the physical and chemical properties of water and chlorophyll- $a$ content for the years 2006 and 2007. 
Grande - mainly due to their lower conductivity, lower hardness, higher turbidity $(F=8.10$ and $\mathrm{p}=0.000$ for the log of turbidity) and lower nitrate concentrations (Kruskal-Wallis test: $\mathrm{H}=16.15$, $\mathrm{p}=0.013)$. In all tributaries, the turbidity was higher than in the Paranaíba (6.2 NTUs), Grande (2.71 NTUs) or Paraná (4.75 NTUs) rivers.

\subsubsection{Seasonal fluctuations}

No significant seasonal fluctuations in limnological characteristics to $\mathrm{pH}$, dissolved oxygen or even calcium were observed. This result demonstrates the stability of the system both spatially and seasonally. The average values for the dry and rainy periods and the results of the t-test are presented in Table 2.

\subsection{Physical and chemical characteristics of the Paraniba River upstream of the São Simão HPP. São Simão Reservoir and tributaries}

The surface water in the environments upstream of the HPP is well oxygenated (Table 3). The lowest verified average in the Preto River, a tributary of the reservoir, was greater than $5 \mathrm{mg} \cdot \mathrm{L}^{-1}$ and differs statistically from the highest average, which was found in the Verde River $(F=2.99, p=0.0012)$ downstream of the São Simão HPP. The $\mathrm{pH}$ of the surface water upstream of the dam was always above 6.0. Furthermore, the average $\mathrm{pH}$ in the Paranaíba River $(6.81+0.52)$, which has the mussel, was lower than that observed in the reservoir of São Simão (average $=7.26+0.68$ ), which has not yet been invaded. In the reservoir, the minimum values of calcium are $2.41 \mathrm{mg} . \mathrm{L}^{-1}$ while the minimum is $3.56 \mathrm{mg} . \mathrm{L}^{-1}$ in the tributaries.

Based on the physicochemical characteristics of the bottom of the water column in the reservoir and the region downstream, we found significant differences in levels of dissolved oxygen $(\mathrm{F}=5.85$, $\mathrm{p}=0.0021$ ). As expected, at the bottom, the waters of the reservoir are less oxygenated, although the average concentration is $6.11 \mathrm{mg} . \mathrm{L}^{-1}$, which is not low or restrictive to the golden mussel (Mackie and Claudi, 2010). Along the Paranaíba River downstream of the dam, the oxygen was higher at the bottom, with an average of $7.36 \mathrm{mg} . \mathrm{L}^{-1}$. The $\mathrm{pH}$ at the bottom did not vary significantly. The $\mathrm{pH}$ at the bottom was mildly acidic downstream of the HPP and the minimum value registered was 5.6 in the Paranaíba River.

\subsection{Hydrodynamic aspects of the system upstream and downstream the São Simão HPP}

The river areas not invaded by mussels were found at stations located upstream of the São Simão HPP (C02 - C14, P03-P05, P15), the Paranaíba River downstream of the dam to station PR1 and the right bank tributaries (T1-T3). These regions (Figure 9) have greater energy.

Particularly along the Paranaíba River, the occurrence of Limnoperna (from PR2 to PR6 stations) is associated with the portions of the river channel that have lower kinetic competence. Through station PR1, the channel is much more embedded, and interference from the backwater area of the Ilha Solteira HPP in the Paraná River downstream of its confluence with the Paranaíba River is not so dominant. In this narrower, faster and more energetic region, mollusc larval densities are significantly reduced, reaching zero at station P00. Molluscs have not established themselves in this area despite the presence of barges, which disperse larvae.

Another aspect of this system is that the water levels and flow rates are determined by the hydroelectric plants, according to the National Electric System Operator in Brazil (ONS).

Table 2. Mean values of chemical and physical variables of water from rivers on the Upper Paraná watershed downstream of the São Simão dam in rainy and dry seasons.

\begin{tabular}{|c|c|c|c|c|c|c|}
\hline & Mean rainy & Mean dry & t-value & df & $\mathrm{p}$ & p 2-sided \\
\hline Secchi Disc (m) & 1.98 & 2.99 & -2.70 & 61 & 0.0090 & 0.0135 \\
\hline Water temperature $\left({ }^{\circ} \mathrm{C}\right)$ & 27.97 & 24.49 & 9.41 & 73 & 0.0000 & 0.0000 \\
\hline Conductivity $\left(\mu \mathrm{S} . \mathrm{cm}^{-1}\right)$ & 39.56 & 38.46 & 0.72 & 73 & 0.4723 & 0.4753 \\
\hline $\mathrm{pH}$ & 6.90 & 6.761 & 1.094 & 73 & 0.2774 & 0.2902 \\
\hline Dissolved Oxygen (mg. $\left.\mathrm{L}^{-1}\right)$ & 7.57 & 7.79 & -1.16 & 66 & 0.2497 & 0.2653 \\
\hline Turbidity (NTU) & 10.34 & 2.83 & 3.047 & 51 & 0.0036 & 0.0222 \\
\hline Alkalinity $\left(\mathrm{mg} \cdot \mathrm{L}^{-1} \mathrm{CaCO}_{3}\right.$ ) & 11.17 & 15.10 & -1.20 & 43 & 0.2384 & 0.2196 \\
\hline Calcium $\left(\mathrm{mg} \cdot \mathrm{L}^{-1}\right)$ & 3.36 & 4.69 & -1.84 & 63 & 0.0703 & 0.0469 \\
\hline Hardness (mg. L-1 $\mathrm{CaCO}_{3}$ ) & 14.15 & 18.52 & -4.86 & 41 & 0.0000 & 0.0001 \\
\hline Total Phosphate (mg. $\left.\mathrm{L}^{-1}\right)$ & 0.02 & 0.01 & 1.38 & 49 & 0.1749 & 0.1639 \\
\hline Nitrate $\left(\mathrm{mg} \cdot \mathrm{L}^{-1}\right)$ & 0.04 & 0.11 & -5.66 & 34 & 0.0000 & 0.0000 \\
\hline Chlorophyll-a (mg. $\left.\mathrm{L}^{-1}\right)$ & 13.59 & 8.14 & 0.60 & 62 & 0.5494 & 0.5740 \\
\hline
\end{tabular}


Figure 10 shows the water level, the flow and the spillway flow compared to the fluctuation of larval densities for the period of interest in the Ilha Solteira reservoir, which marks the downstream portion of this study. From September until March of each year, we registered the lowest water levels in the Ilha Solteira reservoir, compared to the period between April and August. Such fluctuations are explained by oscillations among affluent, effluent and poured flows (ONS, 2012).

The peaks in larval density occurred in October and December 2006 and October 2007. In the subsequent months, there was a sharp decline in larval densities. From January - March 2007, peaks in the flows and poured flows occurred.

\section{Discussion}

In 2006 and 2007, as well as in surveys conducted after 2007, we did not find any invasive bivalves in the São Simão reservoir or the tributaries upstream or along the Paranaíba River from immediately downstream of the dam to the height of the station PR1. Limnoperna fortunei was only found at stations located downstream of the station
PR1. The distance between stations P00 and PR3 (Figure 1), is approximately $100 \mathrm{~km}$.

According to Darrigran and Drago (2000), the average advance of Limnoperna towards the upstream basin of the Prata River is $240 \mathrm{~km}$ /year. However, along the lower Paranaíba River, in the seven years, since 2004, when it was detected for the first time, the species has not been able to colonise more than $100 \mathrm{~km}$ of the river in an upstream direction, which means that during this year, the mussels could have reached station P00. In this region, the river is navigable and constitutes the Paraná-Tietê Waterway, which provides an axis for dispersal of the bivalve. Although adult mussels are regularly seen on the hulls of vessels that travel on the Paraná-Tietê Waterway and on vessels that are docked in the harbours of grain exporters located in São Simão (GO), no larvae or adult mussels are found at the São Simão Hydroelectric Power Plant (HPP). The port of São Simáo is located at the northern end of the region studied; its position is downstream of the São Simão HPP and above the P00 station. This harbour, with vessels carrying soybeans and other products along the Paraná Tietê waterway, is a permanent source of

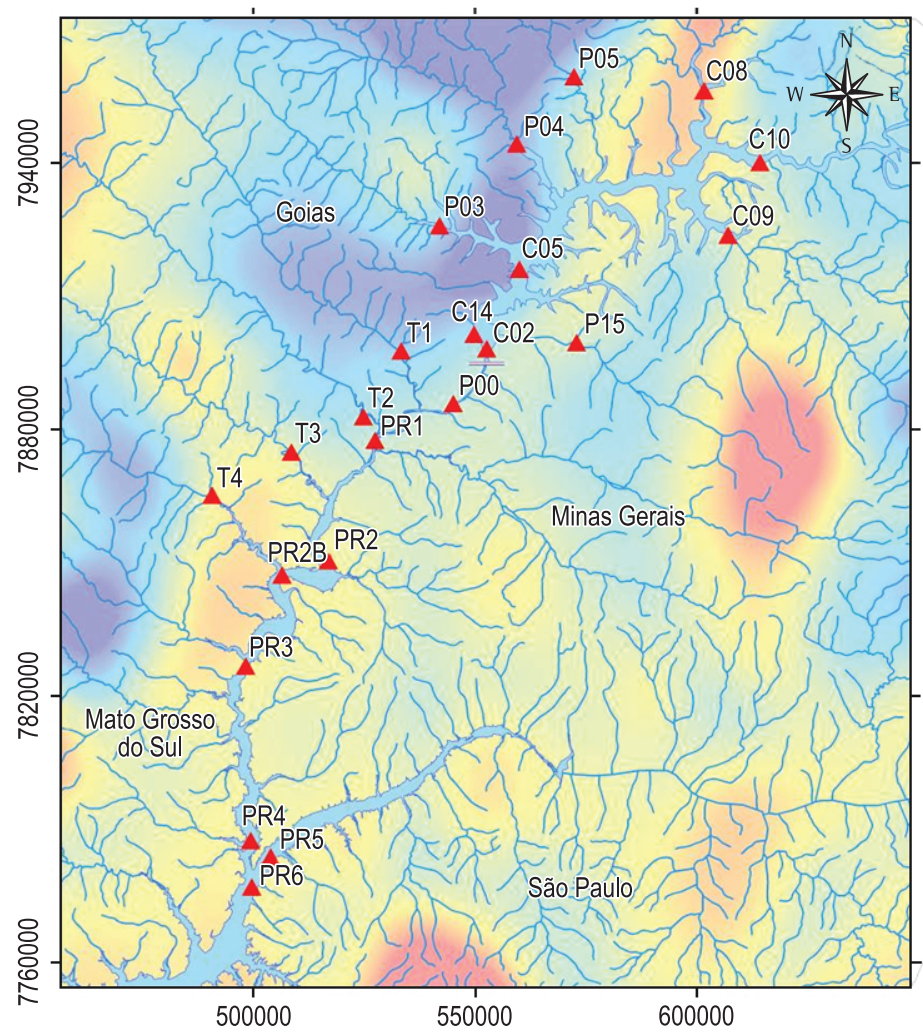

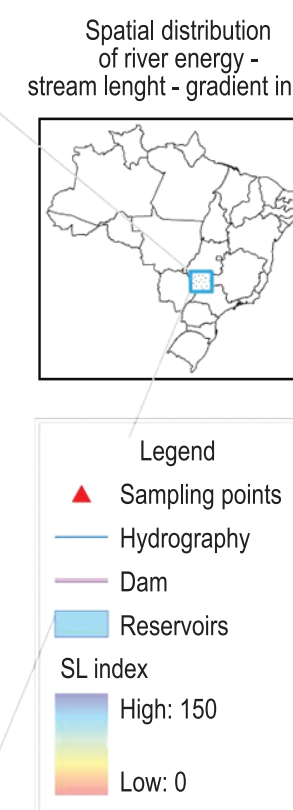

$\begin{array}{lll}0 & 12,5 & 25\end{array}$

Projection - Transverse mercator Zone 22 south - Central Meridian: $45^{\circ} \mathrm{W}$ False easting: $500.000 \mathrm{~m}$. False northing: $10.000 .000 \mathrm{~m}$

Figure 9. Spatial distribution of the energetic force of surface drainage - from SL Index. 
dispersion. Vessels with clusters of mussels attached to their hulls can stay anchored there for days. Despite this traffic, there are no records of larvae in this initial portion, and there are no adults on suitable substrates on the margins or at the centre of the channel.

Our data indicate that, over the period monitored, there was no evidence of an expansion of the area occupied by the mussel, nor a significant increase in larval or adult densities. The species has not established itself in the upper segment of the river (P00 to PR1 stations and the reservoir) despite the active dispersion vector represented by traffic on the waterway and the port of São Simão.

Understanding the factors that control the establishment and integration of the mussel in this waterway must take into account three interactive elements: environmental, biotic and demographic resistance. Environmental factors are the most critical in determining the outcome of invasions, particularly in aquatic systems. However, the success or failure of most invasions depends on the interaction of all three elements (Moyle and Light, 1996).

The suitability of habitats upstream and downstream of the dam was evaluated by comparing the invaded and uninvaded portions and specifically examining physical and chemical characteristics of the water as limiting factors for the species. We found a (temporal and spatial) continuity in the chemical and physical characteristics of surface waters when comparing portions colonised and not colonised by mussels downstream of the dam, particularly when considering that calcium, water temperature, $\mathrm{pH}$ and dissolved oxygen are the limiting factors for mussels. The variations found in the limnological variables in the portion downstream of the dam did not sufficiently explain a pattern of occurrence observed for the invasive species that would explain its absence at the PR1 and P00 points in the Paranaíba River.

At the bottom of the waters downstream of the HPP, the $\mathrm{pH}$ tended to be acidic, but its minimum was 5.6 in the Paranaíba River. Therefore, there was no deterioration in the water quality of the Paranaíba River downstream of the São Simão dam considering the limnological aspects studied.

Some studies have indicated that $\mathrm{pH}$ is a key factor limiting the survival of $L$. fortunei. Ricciardi (1998) suggests that a $\mathrm{pH}$ above 6.4 is the optimum for the mussel and according to a study by Oliveira et al. (2006) based on the occurrence of L. fortunei in the Pantanal Sul-Matogrossense, the mussels only tolerate $\mathrm{pH}>6.0$. But Montalto and Marchese (2003) report an 80\% survival at pH 5.0 after 96 hours, Karatayev et al. (2007) suggested 5.5 as the lower limit for $\mathrm{pH}$. These data all concern the limiting factors for adults; requirements of veligers may be more restrictive. However, based on available

Table 3. Mean, minimum and maximum values of chemical and physical variables of water from the São Simão reservoir and its tributaries in the Upper Paraná watershed.

\begin{tabular}{|c|c|c|c|}
\hline & & Reservoir & $\begin{array}{l}\text { Tributaries } \\
\text { upstream } \\
\text { from the dam }\end{array}$ \\
\hline \multirow{3}{*}{$\begin{array}{l}\text { Water } \\
\text { temperature }\left({ }^{\circ} \mathrm{C}\right)\end{array}$} & Mean & 26.59 & 23.34 \\
\hline & Min. & 22.00 & 20.50 \\
\hline & Max. & 32.10 & 31.40 \\
\hline \multirow[t]{3}{*}{ Secchi Disc (m) } & Mean & 1.92 & 1.15 \\
\hline & Min. & 0.50 & 0.20 \\
\hline & Max. & 3.40 & 1.60 \\
\hline \multirow{3}{*}{$\begin{array}{l}\text { Conductivity } \\
\left(\mu \mathrm{S} . \mathrm{cm}^{-1}\right)\end{array}$} & Mean & 42.29 & 56.67 \\
\hline & Min. & 30.00 & 19.00 \\
\hline & Max. & 57.00 & 159.00 \\
\hline \multirow[t]{3}{*}{$\mathrm{pH}$} & Mean & 7.26 & 7.15 \\
\hline & Min. & 6.01 & 6.15 \\
\hline & Max. & 8.83 & 8.70 \\
\hline \multirow{3}{*}{$\begin{array}{l}\text { Dissolved oxygen } \\
\left(\mathrm{mg} \cdot \mathrm{L}^{-1}\right)\end{array}$} & Mean & 7.82 & 6.93 \\
\hline & Min. & 6.00 & 4.50 \\
\hline & Max. & 9.10 & 8.40 \\
\hline \multirow[t]{3}{*}{ Turbidity (NTU) } & Mean & 4.22 & 18.90 \\
\hline & Min. & 0.00 & 1.00 \\
\hline & Max. & 22.00 & 42.00 \\
\hline \multirow{3}{*}{$\begin{array}{l}\text { Alkalinity } \\
\text { (mg.L-1 CaCO3) }\end{array}$} & Mean & 16.78 & 26.75 \\
\hline & Min. & 12.40 & 17.20 \\
\hline & Max. & 28.00 & 68.40 \\
\hline \multirow{3}{*}{$\begin{array}{l}\text { Total calcium } \\
\left(\mathrm{mg} \cdot \mathrm{L}^{-1}\right)\end{array}$} & Mean & 4.21 & 6.44 \\
\hline & Min. & 2.41 & 3.56 \\
\hline & Max. & 14.30 & 16.08 \\
\hline \multirow{3}{*}{$\begin{array}{l}\text { Hardness } \\
\left(\mathrm{mg}^{-1} \mathrm{~L}^{-1} \mathrm{CaCO}_{3}\right)\end{array}$} & Mean & 18.49 & 28.95 \\
\hline & Min. & 13.90 & 19.40 \\
\hline & Max. & 25.70 & 74.30 \\
\hline \multirow{3}{*}{$\begin{array}{l}\text { Total Phosphate } \\
\left(\mathrm{mg} \cdot \mathrm{L}^{-1}\right)\end{array}$} & Mean & 0.01 & 0.02 \\
\hline & Min. & 0.01 & 0.02 \\
\hline & Max. & 0.01 & 0.03 \\
\hline \multirow[t]{3}{*}{ Nitrate $\left(\mathrm{mg} \cdot \mathrm{L}^{-1}\right)$} & Mean & 0.03 & 0.03 \\
\hline & Min. & 0.01 & 0.01 \\
\hline & Max. & 0.05 & 0.04 \\
\hline \multirow{3}{*}{$\begin{array}{l}\text { Chlorophyll-a } \\
\left(\mathrm{mg} \cdot \mathrm{L}^{-1}\right)\end{array}$} & Mean & 12.36 & 5.26 \\
\hline & Min. & 2.39 & 0.27 \\
\hline & Max. & 101.21 & 12.55 \\
\hline
\end{tabular}


knowledge, $\mathrm{pH}$ is not the limiting factor for mussel dispersal in Paranaíba river system.

Ricciardi (1998) states that the range of calcium suitable for adult survival of mussels in natural waters is greater than or equal to $3.0 \mathrm{mg} . \mathrm{L}^{-1}$. Oliveira (2009) suggests a value of $1.0 \mathrm{mg} . \mathrm{L}^{-1}$ as the lower limit. Unpublished studies by Campos show that adult mortality at calcium concentrations of 1.5, 2.0 and $11.6 \mathrm{mg} . \mathrm{L}^{-1}$ for 15 days is less than $5 \%$ for the golden mussel individuals tested in the laboratory. Upstream of the dam, the minimum values of calcium are $2.0 \mathrm{mg} . \mathrm{L}^{-1}$ in the São Simão reservoir and $3.56 \mathrm{mg} . \mathrm{L}^{-1}$ in the tributaries, so they are always higher than the minimum level required by the mussel. In the Paranaíba River below the dam, the total range of calcium was 1.87-23.5 mg. $\mathrm{L}^{-1}$.

Dissolved oxygen values recorded in surface waters from the invaded and uninvaded environments were not restrictive to the survival of the mussel and could not reduce the risk of invasion or establishment (Mackie and Claudi, 2010). Near the bottom, the waters of the reservoir are less oxygenated, but even so, the average concentration is $6.11 \mathrm{mg} . \mathrm{L}^{-1}$, which is not restrictive to the golden mussel. Along the Paranaíba River, downstream of the dam, the oxygen level is higher near the bottom, with an average of $7.36 \mathrm{mg} . \mathrm{L}^{-1}$. In addition, the

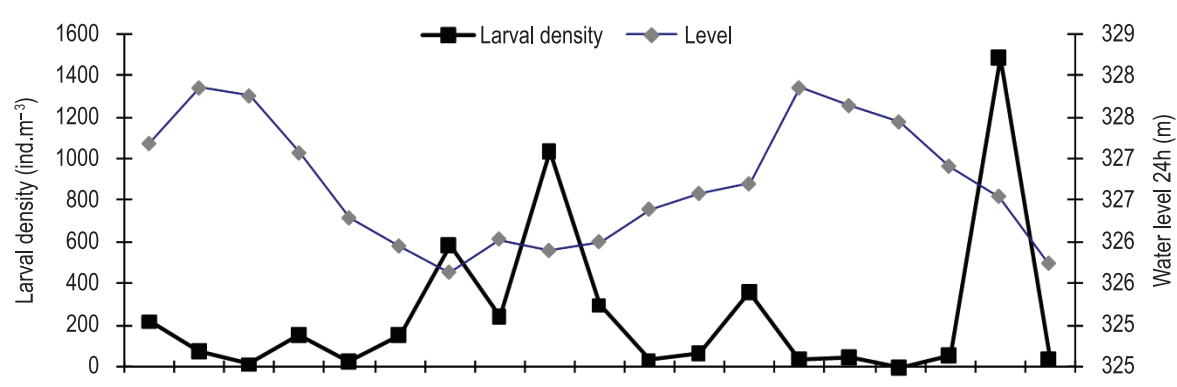

Mar.-Apr.- May- June- July-Sept.- Oct.- Nov.- Dec.- Jan.- Feb.- Mar.- May- June- July- Aug.- Sept.- Oct.- Nov.$\begin{array}{lllllllllllllllllll}06 & 06 & 06 & 06 & 06 & 06 & 06 & 06 & 06 & 07 & 07 & 07 & 07 & 07 & 07 & 07 & 07 & 07 & 07\end{array}$
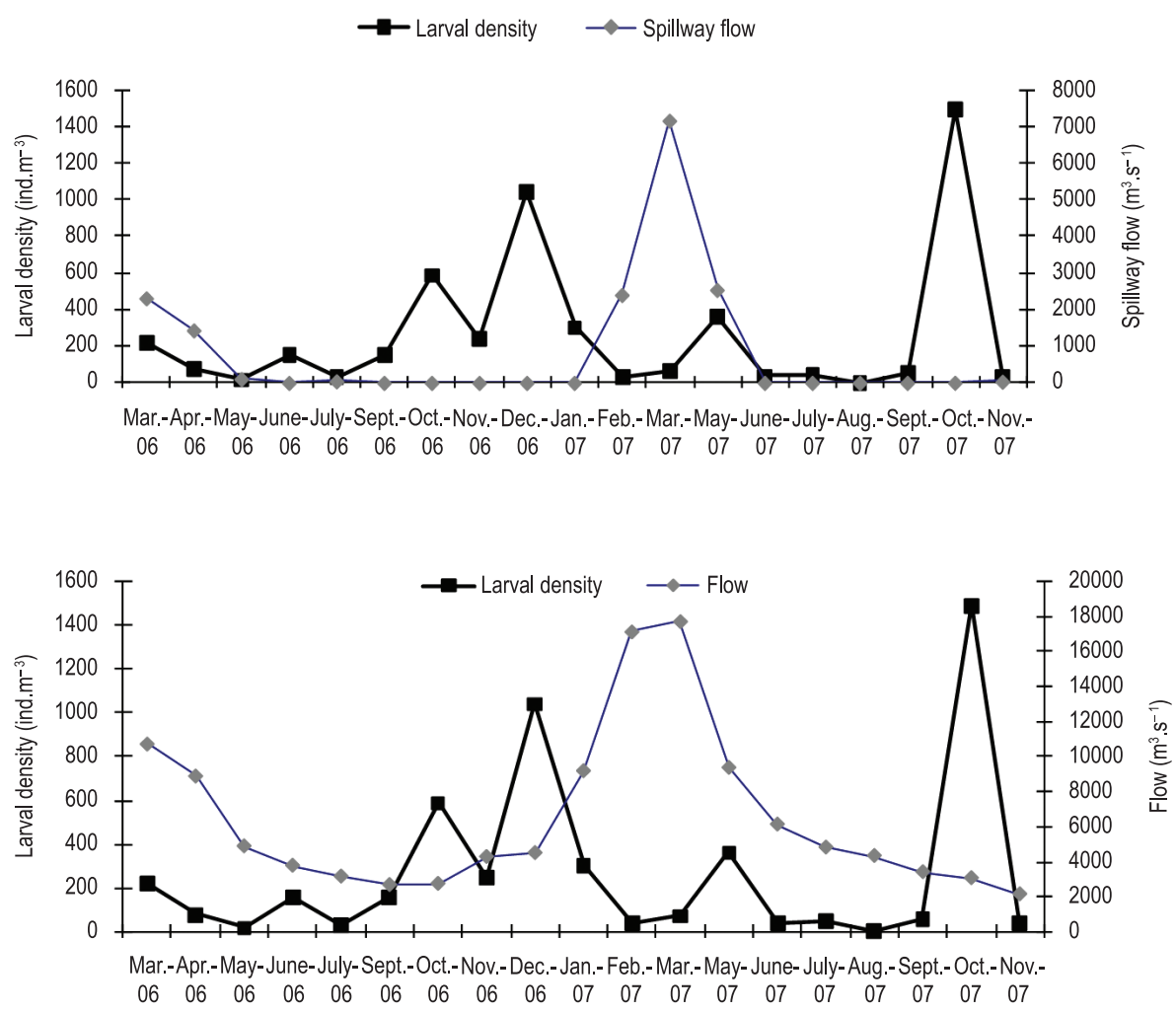

Figure 10. Monthly variation in water level, inflow and spillway flow $\left(\mathrm{m}^{3} \cdot \mathrm{s}^{-1}\right)$ of the Ilha Solteira reservoir from March 2006 to November 2007 (ONS, 2012) and fluctuations in the average larval density. 
São Simão HPP does not have a bottom discharge system that could release low-quality hypolimnetic waters into the river section downstream (CEMIG, oral communication).

In summary, we found that the spatial variation of some important factors, such as the concentrations of dissolved oxygen, $\mathrm{Ca}$ and $\mathrm{pH}$, could not explain the lower probability of occurrence of the invasive mussel. Therefore, these variables do not appear to be determinants and are within ranges favourable for the establishment of this species. Furthermore, significant seasonal variations between the rainy and dry seasons were not found in these physicochemical properties that would change them beyond the tolerance ranges of the mussel.

Once the hypothesis of environmental resistance (habitat suitability) has been discarded, geographic barriers and demographic resistance (pressure of propagules) should be analysed.

Two basic modes of geographic expansion of invasive species have been described: a gradual dispersion from a localised epicentre (the 'reactiondiffusion' model) and a wave-like dispersion punctuated by long distance transport events or 'jump dispersal' (the 'stratified diffusion' model) (MacIsaac et al., 2001). Gradual expansion, on the one hand, is characterised by initial establishment and local population growth, followed by progressive spreading to adjacent areas; in this case, dispersion speed is assumed to be proportional to population growth rates and the time since the initial colonisation. Jump dispersal, on the other hand, is more dependent on the availability of longdistance dispersal agents, both natural (storms and strong winds, flooding events) and man-mediated (shipping, fishing, tourism, boating, etc.).

In this stretch of Paranaíba River, we estimate that the species has advanced approximately $70 \mathrm{~km}$ upstream in 5 years, i.e., an average of $14 \mathrm{~km}$ per year, approaching the speed indicated by Boltovskoy et al. (2006) in the Salto Grande reservoir. In the Uruguay River, where the Salto Grande reservoir is located, the boat traffic is negligible, and the settlement rate is 10 times slower. L. fortunei reached Salto Grande reservoir in 2000 and by September 2003 had colonised only half of this $120 \mathrm{~km}$-long reservoir. Thus, the low number of planktonic larvae is most likely due to the small area populated by adult mussels upstream of the sampling point.

We also believe that a low propagule pressure from upstream is one of the factors explaining the spatial and temporal pattern of colonization of the golden mussel in the river Paranaíba and its absence in the São Simão reservoir: - linked by locks and the artificial Presidente Epitacio channel, all HPPs along the Paraná River upstream along the ParanáTietê waterway have been colonised by the golden mussel (Von Ruckert et al., 2004). However, the mussel has not yet been established in the São Simão HPP, the first situated HPP on the Paranaíba River. This dam is located upstream of the northern stretch of the waterway. It has no locks, and the river above it is not navigable by large vessels. Because of these factors, the traffic of large vessels is not a vector for dispersal of the species upstream of the São Simão HPP. The lake of São Simão is used for activities such as recreation, sports and amateur and professional fishing. However, we suppose that the role of small fishermen in dispersing the mollusc is extremely low because the fishing is very localised, and the movement of fishermen from downstream to upstream is not common in this region, especially from November to February, when the fishing is prohibited according to the law. During this period, which includes the reproductive peak of the golden mussel, the fishing is not allowed until $1500 \mathrm{~m}$ upstream and downstream of dams, waterfalls and rapids, and particularly, in the Paranaíba River portion, between the dam downstream of São Simão HPP and the BR 365 road bridge (IEF, 2011). The absence of large boat traffic upstream of the Sáo Simão reservoir also explains the low rate of colonisation in the Paranaíba River immediately downstream of the dam. Therefore, the absence of colonisation because of the low pressure from propagules from upstream of the dam partly explains the low densities of larvae downstream of the São Simão HPP.

However, the tugboats and barges anchored at the port of São Simão are a centre of dispersion and, by passive diffusion, could provide propagules to the surrounding area. To explain the absence of a population in this area, we must consider other aspects of the hydraulic dynamics of the system studied.

The figure portrayed by the SL Index may be indicative of the importance of the hydrodynamic component to the invasion of $L$. fortunei in the lower Paranaíba River. Particularly along the latter, we found that L. fortunei was established in the regions of the river with lower kinetic competence.

Hydrodynamic stress has been overshadowed by the physicochemical and environmental aspects in several studies using predictive models of spatial distribution of the golden mussel. Different studies 
have concentrated their efforts on building spatial distribution models of $L$. fortunei (Oliveira et al., $2010 \mathrm{a}, \mathrm{b})$, yet few have taken into account the role of shear stress (Bathurst, 1982) in dispersion. However, because $L$. fortunei is an epifaunal species and uses a byssus to fix itself to hard substrates (Morton, 1973), the shear stress of waterways should be central to its distribution.

Clarke and McMahon (1996) investigated the effect of current velocity on byssal-thread production by adult zebra mussels (Dreissena polymorpha Pallas, 1771) and found that current supressed byssal-thread production, which may be due to the mechanical disturbance of attached mussels, and interfered with their ability to press the tip of their foot against the substratum as the thread cures. Another direct relationship can also be expected between the competence of the river and the drag force of planktonic larval stages. Moreover, hydrodynamic forces must be investigated as a possible source of larval mortality. According to Horvath and Lamberti (1999) zebra mussel veligers appear to be highly susceptible to damage by physical forces (e.g. shear), and therefore, mortality in turbulent streams could be an important mechanism limiting zebra mussel dispersal to downstream reaches. Indeed, veliger mortality induced by prolonged exposure to hydrodynamic stresses could be the key factor limiting the distribution of mussels in streams (Horvath and Crane, 2010). Veligers may be particularly susceptible to shell separation while feeding because the shell must be open to allow the velum to sweep food particles into the food groove (Sprung, 1993). An open shell may provide greater surface area and exposed tissue over which shearing forces could act.

Moreover, when graphically comparing flow pulses with the fluctuating densities of larvae, we observed flood peaks occurring after larval density peaks, which could drag the larvae and recruits (late-staged veligers) downstream. Thus, the peak reproductive period for the mussels is followed by a peak flow that generates an increased water speed and consequently could facilitate the downstream dispersal of the planktonic larval forms. The pulses of flow could be considered a hydraulic stress that could minimise the establishment of the species primarily in the portion of the system where lotic conditions and higher energy prevail. The flow pulses could act as a negative vector for larval settlement and reduce recruitment. Pulses could minimise larval establishment in the portion of the system with lotic conditions; higher energy; and a narrow, embedded channel, such as the portion from downstream of the dam to the PR1 station (in this stretch the river width is just $200 \mathrm{~m}$ and at PR2 station, downstream Aporé River confluence, this dimension is more than $2000 \mathrm{~m}$ ).

Our field observations strongly suggest that factors other than the chemical properties of the water, such as the speed, flow and exposure to turbulence or shear during transport in the water courses, can negatively affect the survival of golden mussel veligers larvae, resulting in a low pressure of propagules thereby reducing the chance of golden mussel dispersal and establishment in the region's channels, and indirectly explain the exclusion of Limnoperna from fast tributaries, such as the Claro, Verde and Corrente Rivers. Among the tributaries of the right bank of the Paranaíba River, we recorded the presence of the invasive mussel only at the confluence with the Apore River. This tributary is the closest to the group of major rivers that showed the highest conductivity and the lowest turbidity, and had virtually zero water velocity near the confluence with the Paranaíba River.

\section{Conclusions}

We observed that the advance of the golden mussel into the lower Paranaíba River from the Upper Paraná had a reduced speed of dispersion compared to the average speed of $240 \mathrm{~km} /$ year recorded in the Lower Paraná River. Although more than five years have elapsed since the first observation of the mussel less than $120 \mathrm{~km}$ downstream, there have been no verified records of adults on fixed substrates, natural or man-made, near the dam or the São Simão HPP nor upstream of it. We have ruled out the possibility that the physicochemical aspects of the water restricted the mussel, and we propose a set of factors, that may make this environment less favourable for the establishment of the species.

First, the end of the Tietê-Paraná Waterway just downstream of the São Simão HPP, which drastically reduces the translocation of the species upstream of the dam. Connected with this, we highlight further the absence of a significant traffic of small fishing boats between the rivers upstream and downstream of the reservoir, leading to a nearly non-existent mussel population in the São Simão Reservoir, thus reducing the propagule pressure to downstream areas. In addition, educational campaigns in the region's fishing communities are being developed by companies in the hydropower sector, which may help slow the invasion. 
Finally, the fluvial geomorphology should be considered since it leads some lotic areas to have higher levels of energy, which is less favourable to the establishment and colonisation of the mussel, particularly during the life stage when it is attaching to the substrate. Reservoirs can generate pulses of flow, which applies a hydraulic stress to the larvae and new recruits and discourages the establishment of the mussel population, particularly in areas with predominantly lotic characteristics.

Because streams provide corridors through which golden mussels can invade new eco-systems, determining the limiting factors for mussels can lead to better predictions of future range expansions and ecological effects.

\section{Acknowledgements}

This work was supported by the Electric Power Company of Minas Gerais - Cemig, the Agência Nacional de Energia Elétrica and the Program for Crustal Evolution and Natural Resources, Federal University of Ouro Preto, which granted a doctoral thesis, related to this work. The authors acknowledge Daniel Peifer for his assistance with the SL Index and two anonymous reviewers for their helpful suggestions.

\section{References}

American Public Health Association - APHA. 2005. Biological examination of water. 16th ed. Washington: APHA, AWWA, WPCF. p. 1041-1215.

Associação Brasileira de Normas Técnicas - ABNT. 1995. NBR 12621:1992: Waters - Determination of total hardness by EDTA-Na titulometric method - Method of test. ABNT. p. 1-4.

BATHURST, JC. 1982. Distribution of boundary shear stress in rivers. In RHODES, DD. and WILLIAMS, GP., eds. Adjustments of the Fluvial System. London: Allen and Unwin. p. 95-116.

BOlTOVSKOY, D., CORREA, N., CATALDO, D. and SYLVESTER, F. 2006. Dispersion and ecological impact of the invasive freshwater bivalve Limnoperna fortunei in the Río de la Plata watershed and beyond. Biological Invasions, vol 8, p. 947-963. http://dx.doi. org/10.1007/s10530-005-5107-z

BOLTOVSKOY, D. and CATALDO, HD. 1999. Population dynamics of Limnoperna fortunei, an invasive fouling mollusc, in the Lower Paraná River (Argentina). Biofouling, vol. 14, no. 3, p. 255-263. http://dx.doi.org/10.1080/08927019909378417

BOSSENBROEK, JM., JOHNSON, LE., PETERS, B. and LODGE, DM. 2007. Forecasting the expansion of zebra mussels in the United States. Conservation
Biology, vol. 21, p. 800-810. PMid:17531057. http:// dx.doi.org/10.1111/j.1523-1739.2006.00614.x

BOSSENBROEK, JM., KRAFT, CE., and NEKOLA, JC. 2001. Prediction of long-distance dispersal using gravity models: zebra mussel invasion of inland lakes. Ecological Applications, vol. 11, p. 1778-1788. http:// dx.doi.org/10.1890/1051-0761(2001)011[1778:PO LDDU]2.0.CO;2

Brasil. Ministério de Minas e Energia. Secretaria Geral. Projeto RADAMBRASIL. 1983. Folha SE. 22 Goiânia. Rio de Janeiro: MME/SG, Projeto RADAMBRASIL. vol. 31, p. 764.

CAMPOS, MCS., coord. 2003. Pesquisa para o desenvolvimento de ecotecnologias de prevenção, monitoramento e controle de Limnoperna fortunei (Dunker, 1857): Estudo de caso - reservatório de Volta Grande. Belo Horizonte: Fundação Centro Tecnológico de Minas Gerais - CETEC. 150 p. Relatório Técnico Parcial.

CATALDO, D., BOLTOVSKOY, D., HERMOSA, JL. and CANZI, C. 2005. Temperature-dependent larval development rates of Limnoperna fortunei (Mollusca, Bivalvia). Journal of Molluscan Studies, vol. 71, p. 4146. http://dx.doi.org/10.1093/mollus/eyi005

CATALDO, D. and BOLTOVSKOY, D. 2000. Yearly reproductive activity of Limnoperna fortunei (Bivalvia) as inferred from the occurrence of its larvae in the plankton of the lower Paraná River and the Rio de la Plata estuary (Argentina). AquaticEcology, vol. 34, no. 3, p. 307-317. http://dx.doi. org/10.1023/A: 1009983920942

CHÉTAIL, M. and KRAMPITZ, G. 1982. Calcium and skeletal structures in mollusks: concluding remarks. Malacologia, vol. 22, no. 1-2, p. 337-339.

CHOI, SS. and SHIN, CN. 1985. Study on the early development and larvae of Limnoperna fortunei. Seoul, Korean Journal of Limnology, vol. 1, p. 5-12.

CLARKE, M. and McMAHON, RF. 1996. Effects of current velocity on byssal-thread production in the zebra mussel (Dreissena polymorpha). Canadian Journal of Zoology, vol. 74, p. 63-71. http://dx.doi. org/10.1139/z96-008

CLAUDI, R. and MACKIE, G. 1994. Practical Manual for Zebra Mussel Monitoring and Control. Lewis Publishers. p. 226.

DARRIGRAN, G. 2002. Potential impact of filterfeeding invaders on temperate inland freshwater environments. Biological Invasions, vol. 4, p. 145-156. http://dx.doi.org/10.1023/A:1020521811416

DARRIGRAN, G. and DAMBORENEA, C. 2011. Ecosystem Engineering Impact of Limnoperna fortunei in South America. Zoological Science, vol. 28, p. 1-7. PMid:21186940. http://dx.doi.org/10.2108/ zsj. 28.1

DARRIGRAN, G. and MANSUR, MCD. 2009. Introdução e dispersão do Limnoperna fortunei. 
In DARRIGRAN, G. and DAMBORENEA, C., orgs. Introdução a Biologia das Invasóes. O Mexilhão Dourado na América do Sul: biologia, dispersão, impacto, prevenção e controle. São Carlos: Cubo Editora. p. 89-110.

DARRIGRAN, G., and PASTORINO, G. 2003. The golden mussel Limnoperna fortunei (Dunker, 1857) (Bivalvia: Mytilidae) in the Neotropical region: a 10 years story of invasion. Tentacle, vol. 11, p. 8-9.

DARRIGRAN, G. and DRAGO, E. 2000. Distribucion de Limnoperna fortunei (Dunker, 1857) (Mytilidae), en la Cuenca del plata. Region Neotropical. Medio Ambiente, vol. 13, no. 2, p. 75-79.

DARRIGRAN, G. and PASTORINO, G. 1995. The recent introduction of Asiatic Bivalve, Limnoperna fortunei (Mytilidae) into South America. The Veliger, vol. 38, no. 2, p. 183-187.

DOWNING, JA. and RIGLER, FM. 1984. A manual on methods for the assessment of secondary productivity in freshwater. 2nd ed. London: Blackwell SC. Publ. p. 161-227. IBP Handbook, no. 17.

ETCHEBEHERE, MLC., SAAD, AR., SANTONI, G., CASADO, FC. and FULFARO, VJ. 2006. Detecção de prováveis deformaçóes neotectônicas no vale do rio do Peixe, Região Ocidental Paulista, mediante aplicação de índices RDE (Relação DeclividadeExtensão) em segmentos de drenagem. Revista UNESP - Geociências, vol. 25, no. 3, p. 271-287.

ETCHEBEHERE, MLC., SAAD, AR., PERINOTTO, JAJ. and FULFARO, VJ. 2004. Aplicação do Índice "Relação Declividade-Extensão - RDE" na Bacia do Rio do Peixe (SP) para detecção de deformaçôes neotectônicas. Revista do Instituto de Geociências da USP - Série Cientifica, vol. 4, no. 2, p. 43-56.

HACK, JT. 1973. Stream-profile analysis and streamgradient index. Journal of Research of the United States Geological Survey, vol. 1, no. 4, p. 421-429.

HACK, J. and YOUNG, RS. 1959. Intrenched meanders of the North Fork of the Shenandoah River. Virginia. 10 p. Geol. Survey Prof. Paper 354-a.

HINCKS, SS. and MACKIE, GL. 1997. Effects of pH, calcium, alkalinity, hardness, and chlorophyll on the survival, growth, and reproductive success of zebra mussel (Dreissena ploymorpha) in Ontario lakes. Canadian Journal of Fisheries and Aquatic Science, vol. 54, p. 2049-2057. http://dx.doi.org/10.1139/ f97-114

HORVATH, TG. and CRANE, L. 2010. Hydrodynamic forces affect larval zebra mussel (Dreissena polymorpha) mortality in a laboratory setting. Aquatic Invasions, vol. 5, no. 4, p. 379-385. http://dx.doi.org/10.3391/ ai.2010.5.4.07

HORVATH, TG. and LAMBERTI, GA. 1999. Mortality of zebra mussel, Dreissena polymorpha,veligers during downstream transport. Freshwater Biology, vol. 42, p. 69-76. http://dx.doi.org/10.1046/j.13652427.1999.00462.x

Instituto Estadual de Florestas - IEF. Portaria no 156,13 de outubro de 2011. Dispóe sobre a regulamentação da pesca nas Bacias Hidrográficas dos Rios Grande e Paranaíba, no Estado de Minas Gerais, no período de piracema e dá outras providências. Diário Oficial do Estado de Minas Gerais, Minas Gerais, 14 out. 2011. Caderno 1, ano 119, no. 194, p. 27.

KARATAYEV, AY., PADILLA, DK., MINCHIN, D., BOLTOVSKOY, D. and BURLAKOVA, L. 2007. Changes in global economy and trade: the potential spread of exotic freshwater bivalves. Biological Invasions, vol. 9, p. 161-180. http://dx.doi. org/10.1007/s10530-006-9013-9

KRAFT, CE., SULLIVAN, PJ., KARATAYEV, AY., BURLAKOVA, LE., NEKOLA, JC., JOHNSON, LE. and PADILLA, DK. 2002. Landscape patterns of an aquatic invader: assessing dispersal extent from spatial distributions. Ecological Applications, vol.12, no. 3, p.749-759. http://dx.doi.org/10.1890/10510761(2002)012[0749:LPOAAI]2.0.CO;2

MACISAAC, HJ., GRIGOROVICH, IA. and RICCIARDI, A. 2001. Reassessment of species invasions concepts: the Great Lakes basin as a model. Biological Invasions, vol. 3, p. 405-416. http://dx.doi. org/10.1023/A:1015854606465

MACKIE, GL. and CLAUDI, R. 2010. Monitoring and control of macrofouling mollusks in fresh water systems. Boca Raton: CRC Press. 508 p.

MAGARA, Y., MATSUI, Y., GOTO, Y. and YUASA, A. 2001. Invasion of the non-indigenous nuisance mussel, Limnoperna fortunei, into water supply facilities in Japan. Journal of Water Supply Research and Technology-Aqua, vol. 50, no. 3, p. 113-124.

MALEK, EA. 1968. A guide for the identification of the snail intermediate hosts of schistosomiasis in the Americas. Washington: Pan American Health Organization. no. 168, $121 \mathrm{p}$.

MANSUR, MCD., QUEVEDO, CB., SANTOS, CP. and CALLIL, CT. 2004. Prováveis vias de introdução de Limnoperna fortunei (Dunker, 1857) (Mollusca, Bivalvia, Mytilidae) na bacia da laguna dos Patos, Rio Grande do Sul e novos registros de invasão no Brasil, pelas bacias do alto Paraná e Paraguai. In SILVA, JSV. and SOUZA, RCCL., eds. Água de lastro e bioinvasão. Rio de Janeiro: Interciência. p. 33-38.

MANSUR, MCD., SANTOS, CP., DARRIGRAN, G., HEYDRICH, I., CALLIL, CT. and CARDOSO, FR. 2003. Primeiros dados quali quantitativos do mexilhão dourado, Limnoperna fortunei (Dunker, 1857), no lago Guaíba, Bacia da Laguna dos Patos, Rio Grande do Sul, Brasil e alguns aspectos de sua invasão no novo ambiente. Curitiba. Revista Brasileira de Zoologia, vol. 20, no. 1, p. 75-84. 
MANSUR, MCD., RICHINITTI, LMZ. and DOS SANTOS, CP. 1999. Limnoperna fortunei (Dunker, 1857) molusco bivalve invasor na bacia do Guaíba Rio Grande do Sul, Brasil. Biociências, vol. 69, p. 99-116.

MATSUI, Y., NAGAYA, K., YUASA, A., NARUTO, H., YAMAMOTO, H., OHKAWA, K. and MAGARA, Y. 2001. Attachment strength of Limnoperna fortunei on substrates, and their surface properties. Biofouling, vol. 17, no. 1, p. 29-39. http://dx.doi. org/10.1080/08927010109378462

MONTALTO, L. and MARCHESE, M. 2003. Limnoperna fortunei (Dunker, 1857) (Bivalvia, Mytilidae) tolerance to chlorine, $\mathrm{pH}$ and temperature in experimental conditions. Neotropica, vol. 49, p. 26-34.

MORTON, B. 1982. The reproductive cycle in Limnoperna fortunei (Dunker 1857) (Bivalvia: Mytilidae) fouling Hong Kong's raw water supply system. Oceanologia Et Limnologia Sinica, vol.13, p. 312-325.

MORTON, B. 1973. Some aspects of the biology and functional morphology of the organs of feeding and digestion of Limnoperna fortunei (Dunker) (Bivalvia: Mytilacea). Malacologia, vol. 12, p. 265-281. PMid:4788269.

MOYLE, PB. and LIGHT, TL. 1996. Biological invasions of freshwater: empirical rules and assembly theory. Biological Conservation, vol. 78, p. 149-161. http://dx.doi.org/10.1016/0006-3207(96)00024-9

OLIVEIRA, MD. 2009. Fatores reguladores e distribuição potencial do mexilhão dourado (Limnoperna fortunei) (Dunker 1857) na bacia do alto rio Paraguai e outros rios brasileiros. Belo Horizonte: Universidade Federal de Minas Gerais. 81 p. [Tese de doutorado Ecologia, Conservação e Manejo de Vida Silvestre].

OLIVEIRA, MD., HAMILTON, SK., CALHEIROS, DF., JACOBI, CM. and LATINI, RO. 2010a. Modeling the potential distribution of the invasive golden mussel Limnoperna fortunei in the Upper Paraguay River system using limnological variables. Brazilian Journal of Biology, vol. 70, no. 3, p. 831-840. http://dx.doi.org/10.1590/S151969842010000400014

OLIVEIRA, MD., HAMILTON, SK. and JACOBI, CM. 2010b. Forecasting the expansion of the invasive golden mussel Limnoperna fortunei in Brazilian and North American rivers based on its occurrence in the Paraguay River and Pantanal wetland of Brazil. Aquatic Invasions, vol. 5, no. 1, p. 59-73. http:// dx.doi.org/10.3391/ai.2010.5.1.8

OLIVEIRA, MD., TAKEDA, AM., BARROS, LF.; BARBOSA, DS. and RESENDE, EK. 2006. Invasion by Limnoperna fortunei (Dunker, 1857) (Bivalvia, Mytilidae) of the Pantanal wetland, Brazil. Biological Invasions, vol. 8, no. 1, p. 97-104. http://dx.doi. org/10.1007/s10530-005-0331-0

Operador Nacional do Sistema Elétrico - ONS. Volume útil dos principais reservatórios. Available from: <http://www.ons.org.br/historico/percentual_ volume_util.aspx>. Access in: may 2012.

RICCIARDI, A. 1998. Global range expansion of the Asian mussel Limnoperna fortunei (Mytilidae): another fouling threat to freshwater systems. Biofouling, vol. 13, no. 2, p. 97-106. http://dx.doi. org/10.1080/08927019809378374

SANTOS, CP., WÜRDIG, NL. and MANSUR, MCD. 2005. Fases larvais do mexilhão dourado Limnoperna fortunei (Dunker) (Mollusca, Bivalvia, Mytilidae) na bacia do Guaíba, Rio Grande do Sul, Brasil. Revista Brasileira de Zoologia, vol. 2, no. 23, p. 702-708.

SPRUNG, M. 1993. The other life: an account of present knowledge of the larval phase of Dreissena polymorpha. In NALEPA, TF. and SCHLOESSER, DW., eds. Zebra Mussels: Biology, Impacts, and Control. Boca Raton: Lewis Publishers. p. 39-53.

STRAYER, DL. 1991. Projected distribution of the zebra mussel, Dreissena polymorpha, in North America. Canadian Journal of Fisheries and Aquatic Sciences, vol. 48, p. 1389-1395. http://dx.doi.org/10.1139/ f91-166

VOLLENWEIDER, RA., TALLING, JF. and DEREK, FW. 1974. A manual on methods for measuring primary production in aquatic environments. 2 nd ed. London: Blackwell Sc Publ. 213 p. IBP Hand Book, no. 12 .

VON RUCKERT, G., CAMPOS, MCS. and ROLLA, ME. 2004. Alimentação de Limnoperna fortunei (Dunker 1857): taxas de filtração com ênfase ao uso de Cyanobacteria, Maringá. Acta Scientiarum. Biological Sciences, vol. 26, no. 4, p. 15-23.

Received: 23 February 2012 Accepted: 05 May 2012 